University of California, Hastings College of the Law UC Hastings Scholarship Repository

Faculty Scholarship

2016

\title{
Tools for Change: Boosting the Retention of Women in the STEM Pipeline
}

Joan C. Williams

UC Hastings College of the Law, williams@uchastings.edu

Katherine W. Phillips

Columbia University, kp2447@gsb.columbia.edu

Erika V.Hall

EmoryUniversity, erika.hall@emory.edu

Follow this and additional works at: http://repository.uchastings.edu/faculty_scholarship

Part of the Civil Rights and Discrimination Commons

\section{Recommended Citation}

Joan C. Williams, Katherine W. Phillips, and Erika V. Hall, Tools for Change: Boosting the Retention of Women in the STEM Pipeline, $6 \mathrm{~J}$. Res. Gender Stud. 11 (2016).

Available at: http://repository.uchastings.edu/faculty_scholarship/1434

This Article is brought to you for free and open access by UC Hastings Scholarship Repository. It has been accepted for inclusion in Faculty Scholarship by an authorized administrator of UC Hastings Scholarship Repository. 


\title{
TOOLS FOR CHANGE: BOOSTING THE RETENTION OF WOM EN IN THE STEM PIPELINE
}

\author{
JOAN C. WILLIAMS \\ williams@uchastings.edu \\ Hastings College of the Law, \\ University of California \\ KATHERINE W. PHLLIPS \\ kp2447@gsb.columbia.edu \\ Columbia Business School, \\ Columbia University \\ ERIKA V. HALL \\ erika.hall@emory.edu \\ Goizueta Business School, \\ Emory University
}

\begin{abstract}
This study details how gender bias plays out in everyday workplace interactions in science, technology, engineering, and math (STEM). It is based on indepth interviews with 60 women scientists of color (chiefly professors), and a survey of 557 women scientists (of all races). Different types of gender bias were reported at different rates. Prescriptive gender bias was most common $(76.3 \%$ of women interviewed reported it), followed by descriptive gender bias $(66.7 \%)$ and gender bias triggered by motherhood (64.0\%); just over half of the women interviewed $(55.3 \%)$ reported situations in which gender bias against women fueled conflicts among women. The survey found dramatic differences by race, notably that Black women scientists were more likely than other women to report that they had to prove themselves more than their colleagues, that Asian-American women scientists reported more pressure to behave in feminine ways (and more push-back if they didn't), and Latina scientists were more likely to be called "angry" or "too emotional" if they behaved assertively. The study concludes by introducing a new approach to organizational change to interrupt gender bias, called Metrics-Based Bias Interrupters.
\end{abstract}

Keywords: gender bias; STEM; racial/ethnic minorities; women; science; technology

How to cite: Williams, Joan C., Katherine W. Phillips, and Erika V. Hall (2016), "Tools for Change: Boosting the Retention of Women in the STEM Pipeline," Journal of Research in Gender Studies 6(1): 11-75.

Received 10 August 2015 • Received in revised form 27 January 2016

Accepted 28 January $2016 \cdot$ Available online 25 February 2016 


\section{Introduction}

The scarcity of women in science is well documented, and its impact profound. A 2012 Report from the President's Council of Advisors on Science and Technology reported that a deficit of one million science, technology, engineering, and math (STEM) professionals will result in the United States' workforce if current rates of training persist (President's Council of Advisors on Science and Technology, 2012). It's not hard to see how this hurts the United States' competitive position - and will continue to do so if women in STEM meet more gender bias in the U.S. than do women elsewhere, notably in India and China.

The conventional wisdom is that women haven't progressed in careers in STEM due to the pull of children and early choices not to pursue math and science careers (Moss-Racusin, Dovidio, Brescoll, Graham, \& Handelsman, 2012). Some studies conclude that the relatively low percentage of women reflects these factors and "is not caused by discrimination" in STEM (Ceci, Williams, \& Banett, 2009; Ceci \& Williams, 2011; Ceci et al., 2011).

Yet three recent studies found that gender bias also plays a role. One found that even when math skills were identical, both men and women were twice as likely to hire a man for a job that required math (Reuben, Sapienza, $\&$ Zingales, 2014). A second study found that in academic laboratories in elite universities, male (but not female) scientists employed fewer female than male graduate students and post docs (Sheltzer \& Smith, 2014). A third double-blind randomized study gave science faculty at research-intensive universities application materials of a fictitious student randomly assigned a male or female name, and found that both male and female faculty rated the male applicant as significantly more competent and hirable than the female with identical application materials (Moss-Racusin, Dovidio, Brescoll, Graham \& Handelsman, 2012). These studies are part of a much larger literature on gender bias: experimental social psychologists have documented bias over and over again since the 1980s.

STEM fields provide fertile ground for bias for at least two reasons. First, studies of tokenism document that bias tends to occur more often when women make up less than $15 \%-20 \%$ of a given field, which is common in many fields of science (although no longer in biology) (Kanter, 1977a, 1977b). Second, an influential study by Emilio Castilla and Stephen Benard found that bias is more common in fields, like science, that see themselves as highly meritocratic (Castilla \& Benard, 2010).

This report asks a long-standing question: do the patterns documented in experimental social psychologists' labs reflect what is actually occurring at work for women in the STEM fields? (Mitchell \& Tetlock, 2006). The answer is yes. Gender bias exists, and it exists for women of color: $100 \%$ of the sixty scientists interviewed for this study reported encountering one or 
more of these patterns of gender bias, based on interviews in which we simply described experimental findings and asked women scientists, "Does any of that sound familiar?" (An earlier study found that $97 \%$ of the Black women interviewed were aware of negative stereotypes of Black women, and 80 percent had been personally affected by them (Jones \& Shorter-Gooden, 2003)).

This research is unusual in that it bridges the gap between experimental social psychologists' labs and actual workplaces - and because it examines gender bias among women of color as well as White women. The current body of social psychological work on gender bias has focused almost exclusively on the experiences of White women, leaving the major question of whether these four distinct patterns of bias extend to women of color unanswered.

This report adds to a small existing literature on women of color in STEM. The classic report, The Double Bind: The Price of Being a Minority Woman in Science, was written in 1976; it reports many of the same patterns of bias documented by this report (Malcolm, Hall, \& Brown, 1976). Much of the subsequent research has focused on undergraduates or graduate students rather than science professors, who are the focus of this report. (For recent examples, see Ong, Wright, Espinosa, \& Orfield, 2010; Espinosa, 2011; Reyes, 2011; Ong, Wright, Espinosa, \& Orfield, 2011; O'Brien, Blodorn, Adams, Garcia, \& Hammer, 2014). One of the rare studies that compares White women scientists with women scientists of color found an important difference, namely that the White women reported higher levels of influence in their departments than did the women of color (Settles, Cortina, Malley, \& Stewart, 2006). Another study of a major research university found that $43 \%$ of women of color academics felt they were under close scrutiny, as compared with $33 \%$ of White women and $18 \%$ of White men, and that women of color were also more likely (77\%) to report that they felt they had to work harder to be perceived as legitimate than White women $(58 \%)$ or White men (46\%) (Hollenshead \& Thomas, 2001).

We interviewed sixty scientists who were all women of color. Women of color face "double jeopardy" because they encounter race as well as gender bias (Epstein, 1973; Almquist, 1975). This study explores how the experience of gender bias differs by race. We use the interviews of women of color in science and a survey that quantifies the experiences of White, Black, AsianAmericans, and Latina women in STEM fields to document the little-explored differences between the experiences of White women and women of color, and between different groups of women of color.

It has long been known that the experience of women of color differs from both that of men of color and from that of White women, as a result of a phenomenon known as "intersectionality" (Crenshaw, 1989). But this insight has rarely been explored empirically (for a literature review of the exceptions, and a proposed theoretical framework, see Ridgeway \& Kricheli-Katz, 2013). 
In addition to experiencing the four patterns of gender bias that are common across subgroups of women, women of color also reported racial bias. All three groups of women of color reported that they had to confront negative racial stereotypes. Black women were more likely than other women to report a sense of bleak isolation. Latinas and Black women also often reported being mistaken for janitors - something Williams has never heard in her interviews with White women (Williams \& Dempsey, 2014). But men of color describe similar experiences (Bonilla, 2006).

An important point, sometimes overlooked, is that while bias is rampant, glimpses of hope also emerge from these interviews - situations where women of color experienced support and success despite the difficulties faced. In addition, some of the scientists felt that their cultural and racial traditions armed them well to encounter the challenges they faced.

This report's focus on women of color is designed to address an oft-noted problem: that women's initiatives are seen as "White women's initiatives." Thus an Asian American science professor said her colleague of color "felt that the committee on faculty women really should have been renamed the committee on White faculty women." A common, and indisputable, point is that women of color often are affected by racial as well as gender bias. Much less discussed is that women of color often experience gender bias in ways that differ significantly by race. That is a major focus of this report.

The women we interviewed were divided on whether the bias they faced stemmed from gender, race, or another characteristic. Some women felt what mattered differed depending on the situation. Said a Black lesbian in biostatistics, "There's some times where I feel like being a woman is more problematic than being a person of color, and there are definitely times where it's the reverse. Then there are times where the combination is worse than being - it feels worse than being... a sexual minority.... [I]t's sort of situation dependent.... [I]n various situations, one is at play more than the other and vice versa." Other Black women felt that race was more of an issue. Said another scientist, "I obviously stood out and I felt like I stood out first because of my race and then because I was a woman... I'm the only AfricanAmerican [in my department], but then in terms of my gender, there's a ton of women here. Maybe that's why." This was a common sentiment among Black women.

Asian-Americans and Latinas were more likely to attribute bias to gender than race: "I think it depends on the context. I sometimes have felt the ethnic bias versus the gender bias, but I think overall it's mostly...gender bias," said a Latina whose specialty is anatomy. No matter what a woman's race, bias is draining and demoralizing. An Asian-American in astrophysics found the bias she encountered "tiring and exhausting because it's a constant." A Black woman in biostatistics described "this under-the-surface feeling of uneasiness that you can never quite identify as being overtly... racially dis- 
criminatory, but, man, it certainly feels that way." What's most draining, she noted, were "those little micro kinds of situations, I think that, in some ways, they're probably a little bit worse in that they linger the longest." These micro-aggressions (Sue, Capodilupo, Torino, Bucceri, Holder, Nadal, \& Esquilin, 2007) are often hard to identify by those not affected. This report attempts to make them visible.

This report concludes by introducing a new approach to organizational change to interrupt gender bias, called Metrics-Based Bias Interrupters (Williams, 2014). In contrast to traditional one-off bias trainings, and traditional sensitivity based organizational change initiatives, Bias Interrupters uses a four-step iterative process: 1) identify how gender bias is playing out, if at all, in basic business systems (recruiting, assignments, evaluations, etc.), 2) develop objective metrics to measure bias, 3) implement a bias interrupter to interrupt the bias, 4) see whether the relevant metric improves and, if it doesn't, strengthen or modify the intervention. A compilation of Bias Interrupters is provided at the end of this report.

\section{Conceptual Framework}

The present study begins from an extensive review of literature on gender bias, which repeatedly documents four distinct patterns:

1. Prove-It-Again. Women often have to provide more evidence of competence than men in order to be seen as equally competent (Eagly \& Mladinic, 1994; Foschi, 1996; Foschi, 2000). This descriptive stereotyping (Heilman, 2001) reflects the perceived lack of fit (Heilman, 1983) between being a woman and being a scientist (Nosek, Banaji, \& Greenwald, 2002; Moss-Racusin, Dovidio, Brescoll, Graham \& Handelsman, 2012).

2. The Tightrope. Women often find themselves walking a tightrope between being seen as too feminine to be competent - or too masculine to be likable (Cuddy, Fiske, \& Glick, 2004; Fiske, Xu, \& Cuddy, 1999). The Tightrope reflects prescriptive stereotyping (Heilman, 2001), and stems from the fact that science is seen as requiring masculine qualities - but women are expected to be feminine. Thus women often find themselves pressured to take on dead-end roles, from acting as administrative assistants to being expected to mentor everyone else's students in addition to their own (Allen, 2006). Women also often face backlash for behaving in stereotypically masculine ways, such as being assertive (Prentice, \& Carranza, 2002), angry (Brescoll \& Uhlmann, 2008), or self-promoting (Rudman, 1998).

3. The Maternal Wall. By far the most damaging form of gender bias is triggered by motherhood. Maternal wall bias includes descriptive stereotyping that results in strong assumptions that women lose their work commitment and competence after they have children (Correll, Benard \& Paik, 2007; Cuddy, 
Fiske, \& Glick, 2004), as well as prescriptive stereotyping that penalizes mothers who remain indisputably committed (Benard \& Correll, 2010).

4. Tug of War. Sometimes gender bias against women fuels conflict among women. This stems from the fact that women as well as men are biased against women in traditionally masculine domains (e.g. MossRacusin, Dovidio, Brescoll, Graham \& Handelsman, 2012). In addition, studies show that women who experience discrimination early in their careers tend to distance themselves from other women (Derks, Ellemers, van Laar, \& de Groot, 2011; Derks, van Laar de Groot, 2011). Commonly this is called the "queen bee" syndrome and attributed to the personality problem of an individual woman, but this problem often signals gender bias in the environment.

\section{Methodology}

Respondents were recruited through the Association for Women in Science (AWIS) by sending emails to AWIS members. Five-hundred and fifty-seven scientists responded to an online survey. Sixty women participated in the interview study: twenty each of Latinas, Asian-Americans, and Black women. Erika Hall, then a graduate student at Northwestern University's Kellogg School of Business and now an Assistant Professor of Organization \& Management at Emory University's Goizueta Business School, conducted the interviews.

\section{Overview of Findings}

Our data suggest that gender bias is commonplace in science:

1. Prove-It-Again. Roughly two-thirds of both the women interviewed $(66.7 \%)$ and those surveyed (63.9\%) reported Prove-It-Again bias.

2. Tightrope. About three-fourths (76.3\%) of the scientists interviewed reported Tightrope bias. The survey measured different types of Tightrope bias and found that:

a. About one-third (34.1\%) of the scientists reported pressures to take on dead-end traditionally feminine roles.

b. About one-half reported backlash for stereotypically masculine behaviors such as assertiveness $(53.0 \%)$ and expressing anger $(52.3 \%)$. Over one-third $(38.2 \%)$ reported backlash for self-promotion.

3. Maternal wall. In interviews, nearly two-thirds $(64.0 \%)$ of scientists with children reported maternal wall bias, including the flexibility stigma (Williams, Blair-Loy, \& Berdahl, 2013) when women took parental leave or stopped the tenure clock. Women scientists without children also report being disadvantaged in various ways, notably when they are expected to work longer hours to make up for the schedules of colleagues who do have 
children. Motherhood appears to be a no-win proposition for many women in STEM.

4. Tug of War. Over one-half (55.3\%) of scientists interviewed reported Tug of War patterns. Although three-quarters $(75.5 \%)$ of those surveyed reported that their female colleagues supported each other, several Tug of War patterns emerged. About one-half $(51.4 \%)$ of the scientists surveyed felt that "some women [scientists] have "just turned into men," while 41.7\% agreed with the statement that "some women just don't understand the level of commitment it takes to be a scientist."

5. Sexual harassment. Over one-third (34.5\%) of those surveyed reported sexual harassment.

In addition to these findings, our studies began to document how the experience of gender bias differs for women of different racial groups. Some major findings:

1. Prove-It-Again is more common for Black women than for the other three groups of women: Black women (76.9\%) were more likely than other women to report having to provide more evidence of competence than others to prove themselves to colleagues (Latinas: 64.5\%; Asian-Americans: 63.6\%; White women: $62.7 \%$ ).

2. The stereotype that Asians are good at science appears to help AsianAmerican women with students - but not colleagues. The stereotype of Asian-Americans as "good at science" did not appear to help the scientists surveyed establish their competence with colleagues: they reported more "Prove-It-Again" bias (63.6\%) than White women did (62.7\%) when it came to establishing their competence with colleagues. Interviews confirmed that Asian-American women's experiences were shaped far more by the negative stereotype that women are not good at science than the positive stereotype that Asian-Americans are. This finding raises the empirical question of whether the stereotype of Asians as technically competent (Fiske, Cuddy, Glick, \& $\mathrm{Xu}, 2002$ ) benefits Asian-American men more than Asian-American women. On the other hand, Asian-American women scientists reported less Prove-It Again bias from students (31.7\%), as compared with the other three groups of women (Black women: 56.5\%; Latinas: $50.0 \%$; White women: $43.3 \%$ ).

3. Asian-American scientists were more likely than other women to report workplace pressures to fulfill traditionally feminine roles - and pushback if they didn't. Asian-American scientists surveyed were far more likely than other women to report backlash for stereotypically masculine behaviors such as being assertive $(61.4 \%)$ and self-promoting $(48.4 \%)$. They also were more likely than other women $(40.9 \%)$ to report pressures to play traditionally feminine roles, such as office mother or dutiful daughter. Black women rarely reported pressures to play traditionally feminine roles $(8.0 \%)$ and had 
the lowest levels of backlash for self-promotion (30.4\%). White women and Latinas fell in between.

4. Latinas who behave assertively risk being seen as "angry" or "emotional" - and they shoulder large loads of office housework for both colleagues and students. Interviews found that Latinas who behaved assertively risked criticism for being angry or "too emotional," even when the women themselves reported that they weren't angry - they just weren't deferential. Nearly $60 \%$ of Latinas surveyed noted backlash for expressing anger, as compared with $54.4 \%$ of Asian-Americans, $49.7 \%$ of Whites, and $47.8 \%$ of Blacks. In addition, in interviews, Latina scientists were far more likely than the other groups of women to report being expected - both by colleagues and by students - to do large loads of office housework, including literal housework (such as making coffee), administrative work typically performed by support personnel, and emotion work in helping students with their emotional problems.

5. Black women are allowed more leeway than other groups of women to behave in dominant ways - so long as they aren't seen as "angry Black women." The interviews confirm the finding of two experimental studies (Livingston, Rosette, \& Washington, 2012; Richardson, Phillips, Rudman, \& Glick, 2011) that found that Black women are allowed to behave in more dominant ways than White women - although interviews also noted pushback if one is seen as an "angry Black woman."

6. The Maternal Wall affects mothers of all races. In interviews, $64.0 \%$ of the scientists who were mothers reported maternal wall bias. In the survey, $69.0 \%$ of both Latinas and Asian-Americans described pressure from their families to have children (as compared with $60.6 \%$ of Whites and $57.1 \%$ of Black women). Among those surveyed, Asian-Americans (26.7\%) and White women $(26.0 \%)$ were far more likely than Latinas $(9.1 \%)$ or Black women $(7.7 \%)$ to report that their colleagues had communicated that they should work fewer hours because they had children.

7. Tug of War. When asked whether women support each other, most respondents $(75.5 \%)$ said yes, but Black women were far less likely to agree: only $56.0 \%$ did so. Latinas $(35.5 \%)$ were far more likely to report finding it difficult to get administrative support personnel to support them. In interviews, Black women also reported many instances of conflict with administrative staff. About one-third of both Black women and Asian-Americans reported tokenism - that women in their environments were forced to compete with each other for the one "woman's spot" - as compared with roughly one-fifth of Latinas and White women. Asian-Americans were far more likely $(70.5 \%)$ than other groups to agree that "some women had just "turned into men." Finally, roughly $40 \%$ of all groups of women agreed that "some women just don't understand the level of commitment it takes to be a scientist." 
8. Attributions differ. Black women tended to attribute Prove-It-Again bias to race rather than gender. All groups of women tended to attribute Tightrope and Maternal Wall bias to gender, although race remained more salient for Black women.

9. Sexual harassment. White women (37.2\%) are far more likely to report having been sexually harassed as compared with Asian-Americans (25.0\%), Latinas $(21.9 \%)$, and Black women $(12.5 \%)$. Because the interviews did not ask about sexual harassment, the survey responses offer the only data point. A prior study that lumped social scientists with natural scientists found no difference between sexual harassment reported among Whites and women of color (Settles, Cortina, Malley, \& Stewart, 2006).

\section{Prove-It-Again}

Because women of color don't seem to fit quite as well with "the vision of a scientist," often they have to provide more evidence of competence than do White male scientists in order to be seen as equally competent. Prove-ItAgain bias stems from the perceived mismatch between the typical woman and the brilliant scientist. This perceived mismatch drives several different tendencies:

- Women are presumed incompetent (Gutiérrez y Muhs, Flores Neimann, González, \& Harris, 2012); men are presumed competent (double standards) (Foschi, 2000).

- Women's mistakes tend to be noticed more, and remembered longer, than men's (recall bias) (Heilman, 1995).

- Women's successes often are attributed to luck or other outside causes: he's skilled; she's lucky (attribution bias) (Swim \& Sanna, 1996).

- Objective rules tend to be applied rigorously to women, leniently to men (leniency bias) (Brewer, 1996).

- Superstar women tend to receive even higher evaluations than superstar men, but women who are merely excellent tend to get much lower evaluations (shifting standards; polarized evaluations) (Biernet \& Manis, 1994; Linville \& Jones, 1980).

- If a job requires both experience and education, people tend to choose a man with more education and cite the importance of education to the position; but if the woman has more education, they tend to choose the man with more experience and cite the importance of experience (Uhlmann, Cohen, 2005).

Nearly two-thirds of the women surveyed (63.9\%) and those interviewed (66.7\%) reported that they needed to provide more evidence of competence than others in order to prove themselves to their colleagues. Yet women's experiences varied substantially by race. Black women (76.9\%) were more likely than the other three groups of women to report having to prove them- 
selves over and over again (Latinas: 64.5\%; Asian-Americans: 63.6\%; Whites: $62.7 \%$ ). Interestingly, in the interviews, Latinas discussed colleagues' negative competence assumptions about as much as did Black women, and far more than did Asian-Americans. This finding was not reflected in the surveys.

That Black women felt more Prove-It-Again bias makes sense, given that they trigger two distinct sets of negative competence assumptions, one based on gender, and the other on race (Fiske, 2010; Goff et al., 2008). Less easy to understand is that slightly more Asian-Americans reported Prove-It-Again bias from colleagues than White women reported: perhaps the "model minority" stereotype of Asians as equally competent as Whites (Fiske, Cuddy, Glick, \& Xu, 2002), particularly in technical matters, chiefly benefits AsianAmerican men.

The scientists surveyed also reported having to provide additional evidence of competence to prove themselves to their students, although at lower rates. Black women $(56.5 \%)$ and Latinas $(50.0 \%)$ reported this problem more frequently than did White women (43.3\%) and Asian-Americans (31.7\%). Interestingly, the "model minority" stereotype appears to help AsianAmerican women in STEM more with students than colleagues: while Asian Americans were more likely than White women to report Prove-It-Again problems with their colleagues, they were less likely to report similar problems with their students.

\section{Latinas}

\section{Colleagues' negative competence assumptions.}

A Latina in environmental engineering recalled Prove-It-Again bias from her earliest days in her field when, on her qualifying exams, one of her professors "told me that he was going to ask a question that I was not going to be able to answer and he was going to have me take an extra course." This woman's qualifying exams did indeed contain a question that was impossible to answer without making assumptions. So she made some assumptions, and reached the correct conclusion. Her professor was unimpressed: "even though [her] assumptions were correct and the answer of the question was correct" he still made her take the additional class. "[H]e went as far as knocking on my head and saying, 'Is there anybody there?" Years later, her hands were shaking as she told the interviewer the story. "I was about 22 years old, so I went back to my office in tears." It took her years, she said, "just to be able to see myself again as somebody who actually did know what I was doing back then."

A Latina in geography thought that some people have "these kneejerk reactions that people of color or women of color aren't as competent." A Latina in biochemistry recounted being excluded when her (male) colleagues discussed her own project. When she suggested that it would have been 
appropriate to include her, they looked at her with surprise; "from that day on, I had to really fight and be very proactive about these things."

Sometimes negative competence assumptions play out as hyper-scrutiny. Said a biochemist, "they'll nitpick at the protocol, if that makes sense. Well, did you do something different? Did you change something on the protocol? Did you do it at a different time of day? Was the temperature exactly the same? You just have to address every one of their nitpicking questions, until you've answered them all. It's like, 'Okay, you're out of arguments.' Then they have to accept the fact that okay, yes, you were successful in that, not because you're a woman, but because you can do the experiment, or you can do that project well."

As a result, many Latinas felt intense performance pressure. For these women, working hard is a way to overcome the "Mexicans are lazy" stereotype. Some Latinas felt constantly under pressure to make sure everything they did was perfect, a pattern that has been documented in the lab for Black women (Rosette \& Livingston, 2012).

\section{Students' negative competence assumptions.}

Women also mentioned challenges in getting students to take them seriously. A Latina engineer noted, "Students'...mental image of what their... respected engineering professor should look like is a White, balding male. I enter the classroom and I don't fit that image, so I start out with this, okay, I have to prove myself to them." A Latina chemical engineer noted that "students tend to basically just have a certain level of respect for a male faculty from day one that they don't necessarily have for a female faculty, or for me at least." Prior studies have made similar observations (Turner, Gonzáles, \& Wong, 2011; Stanley, 2006 (citing studies)).

\section{Successes discounted.}

Part of the problem was that Latinas' accomplishments were discounted or attributed to luck. "Even when I went up for promotion," said a Latina biologist, questions were raised about "whether or not I would continue to be doing the things that I was doing, once I got full professor... I had never heard that kind of a comment ever expressed in previous deliberations though. It was a double standard."

\section{Mistakes magnified.}

Several women noted that women were penalized far more than men for mistakes. A Latina statistician recalled a female colleague whose mistake "many years back" was brought up again and again, noting that a male colleague "hasn't been able to let go of that and continues to pound this woman on every possible occasion." This same colleague, she noted "was extraordinarily 
lenient with a male colleague of ours who has done worse than this female colleague of ours and seems to enjoy - 'Oh, he didn't mean that."'

\section{The stolen idea.}

Several women also reported situations where women suggest an idea only to have it overlooked, only to have the idea taken up when it is repeated by a man. Said a Latina environmental engineer, "I would say something in a meeting and it would go on deaf ears. And then somebody else would say the exact same thing and there would be the, 'Wow, that's such a great idea." A Latina statistician recalled, "[Y] ou say something in a meeting, you throw an idea out on the table, nobody picks up on it. Then, a little while [later] one of your male colleagues throws the exact same idea on the table and everybody goes, 'Oh, that's a fantastic idea.'”

The Latinas interviewed typically attributed their Prove-It-Again challenges to gender rather than race. "[A]s a woman in engineering, very, very, very few women, right, mostly males, you are kind of wired into thinking that you have to try harder... And you probably will have to work twice as much as your male colleagues," remarked one woman. Another Latina, a statistician, noted "You are young and you are male, you can do it. You are older and you are female, they don't want to waste time on you, until you prove the contrar."

Prove-It-Again problems were perceived to have concrete consequences. A Latina engineer commented, "I have seen some of my [female] colleagues get higher funding rates, higher number of publications, higher service achievements, have their promotions delayed because it was considered that they didn't have enough achievements."

A Latina in microbiology and biochemistry commented that the Prove-ItAgain problems she encountered in the early years of her career stopped when she entered an environment that was gender balanced: "[D]uring my postdoctoral fellowship where I was the only female in a postdoctoral lab of six men, and the PI was also a man... I always felt like I had to do more to prove myself in that lab. Even in just simple lab meetings, we would each have to kind of say what we did that week and go over our data. And I always felt like I was getting drilled... [W] hereas the other guys, they would just kind of say, 'Oh, yeah, and we sat around and did X,' and they were just believed immediately." Now that this woman is in a department that is half male and half female, she notes that this does not happen anymore.

Some Latinas felt that unfair treatment just rolled off their backs. A biology professor noted, "I was raised in a culture where women are sort of stronger in a lot of ways. Women have learned to take over responsibility for their families and be the ones in charge. Whether you have a man or not, you have to make things happen... I feel that that has given me strength in science where I don't believe paying much attention about what other people 
might think or not think and just go for what I think I want to do and that I need to do. I just don't give up. I'm from Puerto Rico." A woman of Mexican descent agreed. "My mother is an extremely - she's a go-getter. My greatgrandma grew up during the Mexican Revolution, and she was one of those ones that picked up guns and went fighting for the cause. It comes from generations of very assertive women."

A strong sense of right and wrong helped others: many Latinas in science adopted a "what does not kill you makes you stronger" attitude, viewing those who exhibited prejudice as weak and themselves strong because they worked hard and took pride in the results of their work.

\section{Black Women}

\section{Colleagues' negative competence assumptions.}

The experimental finding that Black women have to provide more evidence of competence (Rosette \& Livingston, 2012) definitely resonated with the women interviewed. Said a Black microbiologist, "[I]t's a huge barrier, how you're perceived as a capable scientist." A Black biochemist noted, "You always have to prove yourself..., to show skill. I've never, ever had anything easy." She attributed the problem chiefly to gender, recalling a time when she and her advisor, a White woman, stood virtually alone watching the traffic go to the poster of a White male colleague, whose was on a closely related topic.

More commonly Black women attribute their Prove-It-Again problems to race. Said a Black woman in medical imaging, "that initial expectation of not being professional or whatever and - or not being taken seriously until they hear me, I think that's more because I'm Black than because I'm a woman." A statistician agreed, suggesting that when she presented to an audience, the audience assumed a lack of merit in her results. A prior study found that $63.6 \%$ of Black faculty report subtle racism as a source of stress - over 20 points higher than for any other group of faculty (Hurtado, 2011).

Other respondents expressed less certainty about whether race or gender was the issue. "It's challenging because you don't know if you're working twice as hard because you're a woman or if you're working twice as hard because I'm African American," said a mathematician. A Black microbiologist said, "Yes, we must prove it again and again. We have two strikes against us and each is addressed separately." The prevalence of this experience has been noted in other studies (Stanley, 2006).

Still others felt gender and racial bias were additive. A Black biostatistician noted that she sometimes needed to put her foot down. "[When] it's moved to a place that's almost ugly, where I've had to remind people, 'Look, I have this degree from this very prestigious place. Yes, you have a different degree in a different area, which makes you knowledgeable in a very different area 
that's not Statistics, and if you're going to challenge me on this - well, I won't be challenged on this."

Black women are "presumed incompetent" (Gutiérrez y Muhs, Flores Neimann, González, \& Harris, 2012) not only in research but also in teaching. A Black statistician recalled when an administrator asked her how her teaching was going. "'You're not having any problems? Everything's going okay?" She said everything was fine; later she found out that "a student had called the office and complained about a professor. For some reason, naturally it was assumed that it was me, okay?" The student complained about another professor.

\section{Successes discounted.}

A Black biochemist reported that an evaluation said, "she's bright, she's big, but she needs a lot of supervision." Note how her success was discounted.

\section{Objective rules applied rigorously to women, leniently to men.}

A Black biologist noted an example of leniency bias - when objective requirements are applied rigidly to some but leniently to others. She prepared a document and "I didn't put it in an envelope. That was it. I just gave it to the staff member and didn't put it in an envelope. The faculty member came back to my office screaming and raging about anybody could have seen this paperwork, it's private and confidential. It was just a hiring form."

Some women were philosophical about their Prove-It-Again challenges. Many of these women grew up with the knowledge of an "uneven playing field." Said a Black statistician, "I turn it around as a motivator. Because I turn it around into a positive. It helps motivate me to push harder."

\section{Asian-American Women}

Asian-American women in STEM, at least in theory, are in a different situation than Latinas and Black women. First, Asian-Americans are not an underrepresented minority in STEM. Second, Asian-Americans are seen as equal in competence to Whites (Fiske, Cuddy, Glick, \& Xu, 2002), particularly in technical matters. One woman used the model minority stereotype strategically. An Asian-American physicist very self-consciously played off the stereotype that "Asians are naturally talented in STEM fields" to counter the negative stereotype that women aren't. Her strategy was to make sure she was seen as an Asian in STEM rather than a woman in STEM: "I'm more acceptable, if you will, as an Asian woman scientist rather than a woman scientist."

\section{Colleagues' negative competence assumptions.}

Yet this sentiment was surprisingly rare. Most of the Asian-American women interviewed reported experiences similar to those reported by Latinas and 
Black women. "I have felt always under...extra scrutiny," noted an AsianAmerican woman in astrophysics. She had the sense that she needed to display her competence "in many more settings than they are required of men, of White women, whatever.... -[Y] ou have to prove yourself all the time and that, yes, not a whole lot is taken on promise." An Asian-American in statistics described the attitude: "If you're perfect we might accept you, but if you're not perfect, forget it." She continued, "Your expertise constantly being questioned is probably the biggest thing - you know, people just assuming that you're not going to be able to cut it." Asian-Americans also reported disrespect: a geophysicist recalled when her colleagues told her students that she would not get tenure, and "it felt so wrong."

\section{Students' negative competence assumptions.}

An Asian-American biochemist reported her sense, when she starts a class of "an uphill kind of battle...I get the impression that students don't believe that I know what I'm supposed to know...?" Said an Asian-American statistics professor, "I think my worst experience was probably an almost all male engineering stats course where, if I pointed out a couple of different ways of doing a problem, the teaching evaluations came back saying 'She doesn't know what she's talking about." When her White male colleagues did the same thing, they were labeled "inventive" and "smart."

To enhance their authority, the Asian-American women interviewed tended to be much more formal than their male colleagues. "Because if I went into my class wearing cut-offs with holes in them and a t-shirt, I just would not get any respect at all - particularly when I was younger - whereas my male colleagues of the same age could get away with that," said an AsianAmerican in statistics. So she dressed more formally, and "tend[s] not to be jokey. My male colleagues can joke around a lot." People "have told me to loosen up and I honestly don't know what I've said in response, but I just had a feeling that if I started to loosen up I would lose respect."

\section{Successes discounted.}

Other Asian-American women reported that their successes were discounted. One described her department chair saying that she got grants not due to merit but to politics. An Asian-American woman in statistics recalled that she was the only one who had a tenure track position when she finished her program. Despite the fact that she had three publications while her White male colleagues had none, she was told that she had gotten the job because she was a woman.

These assumptions have concrete consequences, noted an Asian-American immunologist: "I got my big R01 and then looked for the position." She was told she "needed to wait for a year to be associate professor in order to move your lab and also he gave me a lot of - I think it's excuses." She accepted 
the job at an assistant professor rank nonetheless because she wanted a shorter commute - only to have a less credentialed man hired as an associate professor. Even when she managed to get her rank changed to associate, her salary remained unchanged, despite the fact that she had brought in another prestigious grant. She said this kind of thing was common.

\section{The stolen idea.}

An Asian-American biochemist recalled that often her idea was "just portrayed as somebody else's idea. And then they would discuss about it, basically not giving me any credit for what I was saying." She got so tired of this that she began to put her ideas in an email before a meeting, so everyone knew which ideas originated with her.

A geneticist noted that things had improved when more Asian-American women entered leadership positions. "[T]hat has helped changed the atmosphere."

\section{The Tightrope}

Due to prescriptive gender bias, women walk a tightrope between being seen as too feminine, and so liked but not respected - or too masculine, and so respected but disliked (Fiske, S. T., Cuddy, A. J., \& Xu, J., 1999). Studies have documented that Asians (men as well as women) are seen as more feminine than Whites, while Black people are seen as more masculine than White people (Goff, Thomas, \& Jackson, 2008; Johnson, Freeman, \& Paulker, 2012; Galinsky, Hall, \& Cuddy, 2013). So it comes as no surprise that AsianAmerican women encounter more "too feminine" problems - and Black women encounter fewer - than do other women. White women and Latinas generally fall somewhere in between.

Asian-Americans surveyed were more likely (40.9\%) than other women to report pressures to play traditionally feminine roles such as office mother or dutiful daughter, as compared with White women (35.9\%) and Latinas $(28.1 \%)$. Black women rarely identified this as a problem $(8.0 \%)$.

Asian-Americans also more often reported backlash for stereotypically masculine behaviors. Most striking, fully $61.4 \%$ reported pushback for assertiveness. It seems that the stereotypes of Asians as passive mean that AsianAmerican women who aren't passive seem more transgressive. The other three groups of women also reported pushback for assertiveness, but at lower levels: $53.2 \%$ of White women, $50.0 \%$ of Blacks and $46.9 \%$ of Latinas.

The survey suggests that the racial stereotype of the "fiery Latin" may leave more room for Latinas to behave assertively, but the same stereotype disadvantages Latinas who show anger. Latinas were more likely than other groups of women to say they did not feel free to express anger at work: $59.4 \%$ reported this, as compared with $54.4 \%$ for Asian-Americans, $49.7 \%$ 
for Whites and $47.8 \%$ for Black women. Moreover, in the interviews, Latinas often reported that they were faulted for being angry or "too emotional" when they behaved assertively - something never reported by women from other groups.

Asian-American women are more likely than women from other groups to be policed into femininity, and penalized for stereotypically masculine behavior. The final evidence of this pattern concerns self-promotion. Nearly half $(48.8 \%)$ of Asian-Americans surveyed reported backlash for selfpromotion, as compared to roughly a third of women from other groups: $37.3 \%$ of Whites, $31.1 \%$ of Latinas, and $30.4 \%$ of Black women.

The survey contradicts an experimental study that found that Black women are allowed to behave in more dominant ways than White women without pushback (Livingston, Rossette, \& Washington, 2012). In our survey, Blacks and Whites reported backlash for behaving assertively and showing anger at about the same rates.

In a counter-intuitive finding, White women (41.8\%) were most likely to report they are asked to do more service work than others, a higher level than Black women (37.5\%), Asian-Americans (32.5\%), and Latinas (31.3\%).

All four groups of women tended to attribute Tightrope issues to gender, although race remained more salient for Black women.

\section{Asian-American Women}

\section{Asian-A mericans often encountered pressures to play traditionally feminine roles - and pushback if they didn't.}

Asian-American women surveyed reported that they had encountered pressures to play traditionally feminine roles such as office mother or dutiful daughter at much higher rates than other women. Asian-American women were also much more likely to report backlash if they engaged in stereotypically masculine behaviors, such as self-assertion (61.4\%) and self-promotion (48.8\%), suggesting that the stereotype that Asian-American women are more feminine than Whites is also a stereotype that they should be more feminine.

The stereotype of Asians as passive plays a role. A geophysicist noted the expectation "that Asians are supposed to be very passive. And when you add women to that, they really don't expect Asian women to stand up for themselves, or they expect the dragon lady, the extreme opposite. You can't just be a normal person. There's no expectation for you to be normal." An Asian in viral immunology agreed, saying that, as an Asian woman, she was seen as someone who "should be like feminine, yeah. Shouldn't be aggressive."

Some refused to conform because they felt that doing so undercut their authority. "I just feel like it's kind of sad you have to portray yourself as a tough bitch in order to stand on your ground. It's hard," mused an immunol- 
ogist. "I'm very candid and I do not hesitate to open my mouth and that was probably not the submissive female person," said an Asian-American biologist. "I think that being an oriental female immediately started, I guess, having a reputation of being a dragon lady." Colleagues in other departments told her to watch her back. "Early on when I started working here, a faculty colleague of mine said..., 'I can hear you way down the hall because your balls clang."”

The Tightrope is very narrow for Asian-Americans: one soil microbiologist, who reported being penalized for her masculine style, also reported having been penalized earlier in her career for being too feminine. Now a professor, she talks with students about being assertive, and about the "difference between being assertive and being a bitch."

Sometimes colleagues' bias was very open: "I've gotten remarks like 'I didn't expect someone that was Indian... and female to be like this," said an Asian-American soil microbiologist. She found it a challenge to "fit some sort of stereotype of this, I don't know, quiet, subservient woman or something." Again, the Tightrope was narrow: "if a woman promotes herself, then she's too forward or too aggressive." Her solution was to signal masculinity through clothing, which is "my way of not really being masculine but kind of conforming to a dress code so that I am respected."

An Asian-American physicist perfectly articulated her dilemma, saying that the Tightrope sounded "very, very familiar. And I think it's a struggle that most women or even I go through is how do you portray yourself? I mean, where is the balance, right? I mean, you....are a woman...you don't have to be a man. But, at the same time, if you want to fit in, do you have to behave like the men? And I think I see that a lot. And I know of a lot of women who go through this struggle of how should you portray yourself and be respected for what you are.... I still find that a struggle."

Politically adept women riffed off stereotypes to keep colleagues off balance. "[I]f you're a young man you're a boy genius," said an astrophysicist. "But if you're a young woman, you are so threatening that, in order to be able to cope and to be liked and not intensely disliked by everybody else," things get difficult. "I have had to become as amiable as possible and a group player all the time, not looking out for myself, so damp down my ambition in some ways.... I rarely talk about the prizes I get, the media attention I get. I mean, I keep it all really damped down. But, now in the age of the Internet, right, everybody knows everything." This is "gender judo:" using feminine stereotypes that typically hold women back to, instead, propel them forward (Williams, 2014). While this strategy had proved successful in managing backlash, she believed she'd also paid a price for downplaying her accomplishments 


\section{Self-promotion challenges.}

Women of all groups often struggle with self-promotion, which often is seen as appropriate in men ("he knows his own worth") but distasteful in women (Rudman, 1998), who are expected to be demure, modest, and helpful (Prentice \& Carranza, 2002). Many Asian-Americans find self-promotion particularly difficult. "It's our upbringing that you're taught to be humble and not boast about your achievements and give credit to others and being boastful is just being rude.... If people find and appreciate, that's good for you. If not, that's okay is what we are taught. And so, it's so inherent in us that in a society where it's more self-promoting...that it's really hard.... Even those who do it eventually, it takes a very long time to learn that. And you pay a price for that," said a geophysicist.

\section{Students' stereotypes.}

The "den mother" role is common for Asian-American women professors. Sometimes it's a self-conscious strategy - gender judo - to dodge pushback for being seen as too accomplished or too masculine by adopting a feminine persona. Often, though, the femininity feels mandated and uncomfortable, as students demand attention and emotional support from women that they rarely require of male professors. Said a physicist, "The weaker female grad students said 'Oh, I thought, as a woman, she would understand my problems.' They expected me to be sort of motherly towards them and spend time counseling them and so on, which is not my job." A statistician reported similar experiences, saying that students "expect me to be more helping - you know, always willing to help. Where a male faculty member could just refuse and not have that negatively affect him. Whereas if female faculty members just refuse, that can negatively affect them."

Again women reported that things got easier when they transitioned to environments with more women colleagues in professional roles. A statistician noted that in her current department, female administrators had been around for a long time, so "women can behave quite assertively and aggressively and be respected." She concluded, "so things are good."

\section{Black Women}

While Asians are seen by Whites as more feminine than Whites, Black women are seen by Whites as more masculine (Galinsky, Hall, \& Cuddy, 2013). So it is not surprising that Black women reported both less pressure to play traditionally feminine roles and less backlash for behaving in stereotypically masculine ways. Black women reported rarely feeling pressure to play traditionally feminine roles such as office mother or dutiful daughter: only $8.0 \%$ of Black women did. (Other women's agreement ranged from $28 \%$ to $41 \%$.) 
A microbiologist described how she did not suffer fools gladly. When students come to her for tea, sympathy, and deferred deadlines, "I'm like, I do keep count of how many grandmothers people have. You can't do it three times."

Thus Black scientists surveyed reported the lowest level of pushback for self-promotion (30.4\%, as compared to $31.3 \%$ for Latinas, $37.3 \%$ for White women, $48.8 \%$ for Asian-Americans). Black women also were less likely than other women to report that they did not feel free to express anger at work (47.8\%, as compared to $49.7 \%$ of Whites, $54.5 \%$ of Asian-Americans, and $59.4 \%$ of Latinas).

Studies show that open expressions of anger tend to increase the perceived status of a man, but decrease that of a woman (Brescoll \& Uhlmann, 2008), but the extent to which this is true may differ based on race. An experimental study found that Black women are less likely than White women to encounter backlash for behaving in dominant ways (Livingston, Rossette, \& Washington, 2012), and the interviews contain many examples of Black women saying that dominant behavior works for them. Said a Black woman in medical imaging, "I've never really dealt with being thought of as a bitch, but I have - I kind of aspire to that a little bit because I see, at this university at least, that - actually it's a very effective perception to have." She continued, "And when I am most successful is when I come out of my passive mode... I am assertive, that's when I am most rewarded. I won't say that's when I'm most productive, but that's when I'm most rewarded." A Black statistician noted that she felt she could get respect for being like a prototypical man - aggressive or assertive. So did a mathematician, who embraced "the perception of the angry Black woman is that we're very, very strongwilled. We don't take any mess and we get the job done, right?"

Other women agreed. A Black statistician noted, "I certainly can't walk in the classroom and come off as being timid, right? Because then students will try and walk all over me. You go in there, you're assertive, you lay down the rules of the syllabus on the first day. At least if you come off on that first day as being stern - I'm not saying you have to be nasty, of course, but very set and this is what you want to do, this is the goal of the class, this is my role, this is your role. It lays down the groundwork." A prior study found that Black professors (both men and women) tend to be judged as significantly less competent and legitimate than White and Asian-American professors and were seen as having fewer interpersonal skills than Whites (Bavishi, Madera \& Hebl, 2010).

A doctor recalled sending an email when she was truly annoyed with a colleague: "When I finished the email and read it, you could tell that it had a bite to it. [Laughter.] This person was someone that I really didn't care if they got the bite because I wanted "em to get the bite." Her partner noted that the email had an attitude and asked "Now, why did you send that?' I said, 'Because I was ticked.' He goes, 'Well, that had an attitude to it.' I said, 'I 
know.' I said, 'I meant for it to have an attitude." She sent it to a colleague who "has this attitude of, well, I'm in charge and I know what's best and kind of push over people. I wanted him to know I wasn't just gonna go away or just back off just because this is the way he said it. I sent this email and, yeah, it had a bite to it. Within ten minutes - this is at 9:00 at night - within ten minutes I got a response from this guy and the response was, 'Oh, I am so sorry. I didn't realize." These findings echo an earlier study of physics graduate students that found that they strategically adopted a "loud Black girl" persona (Ong, 2005).

In sum, the interview evidence appears to confirm the experimental evidence that Black women can behave in more dominant ways than White women and Asian-Americans; the findings with respect to Latinas are murkier. Yet the picture is complex: the survey evidence appears to contradict that finding. In the survey, White women $(52.3 \%)$ and Black women $(54.2 \%)$ report pushback for being assertive with about the same frequency as each other; with Latinas not far behind (46.9\%). More research is needed.

\section{Avoiding the "angry Black woman" stereotype and other backlash.}

There are limits. A statistician noted, that the Tightrope is "particularly sensitive" because "you have to avoid the stereotype of the "angry Black female," which "diminishes your opinion and the weight of your argument." A microbiologist recalled getting testy with a colleague who wanted to correct a student's technique in her research lab "-they were pretty much saying that what I was telling the student was wrong." She let them have it. "I pretty much bluntly invited them to leave my lab, and told them that if they had issue with things that go on in my lab, to address me first of all, and if I couldn't give them satisfaction, they were free to take it up with the administration, but unless they saw an imminent danger." She noted, "I'm calm. I don't raise my voice... Because if I were as assertive as some Caucasian colleagues that are male, I would be called a mad Black woman ... For that reason, I choose to - and actually, it's just my personality to be soft-spoken."

A doctor also reported self-editing to avoid backlash, saying that she dressed more femininely because, if she "dressed like Hilary Clinton, wore pantsuits all the time or just kind of didn't care as much about her appearance," she felt she would be regarded as "aggressive as opposed to just neutral. I think a plain-dressing Black woman would be taken as aggressive or as - and then, especially with the hair." Whether to let one's hair grow natural, of course, has long been a delicate issue. One Black woman recounted, after becoming department chair, how a colleague had "spent 45 minutes telling me how I needed to dress more appropriately for the position that I was going to assume" and that she "should wear more skirts and apply 
make-up...I have been told that wearing my hair naturally was not a professional kind of hairstyle."

Other Black women describe backlash as a problem and gender judo as a solution. A biologist who noted that she tends to be "a very direct speaker" said that her Chair got "very angry and was like don't talk to me like that." She had heard male colleagues talking that way, without incident. But she felt she had to "put cotton candy in my mouth and, oh - I had to do very - a lot of deferring. 'I can't do this without your help, I really need you to do this,' if you - and I had to put him in that masculine 'I'll take care of it role,' and I had to take the feminine 'I need you to help me, I need to be saved' role. And a lot of times, that was how I had to deal with him in order to get what I needed to get things done." This interviewee felt that White women could get away with being direct, "whereas with me, it was seen as more threatening."

A cancer biologist exemplified a common outcome of "stereotype threat" (Steele, \& Aronson, 1995) - when someone vulnerable to confirming a negative stereotype shapes their behavior in order to avoid doing so and, as a result, becomes less effective. To avoid being seen as an "angry Black woman" she tried not to raise her voice or to be too animated, which, she acknowledged, contributed to her timidity in meetings.

The single most shocking story was told by a microbiologist who, earlier in her career, suffered a traumatic brain injury. When some White males who worked for her came to visit "I asked them the questions that a boss would ask, like "Where are we with the project? Did you take care of this and that and that?"” The hospital staff thought she was "unnecessarily brusque, undeferential" and that she "needed to stay in rehabilitation longer until I started acting like a woman." One of her colleagues suggested she act the "Southern belle" so "I dropped my IQ by several points and started looking for little things to decorate myself with." She raised the pitch of her voice and chose pink hospital gowns. "All the sudden, they let me out."

This scientist proceeded to describe the Tightrope in classic terms. "[I]t's a fine line you have to walk, because sometimes I do find myself trying to not come off too aggressive, because I know it can be, I guess, viewed as she is bitchy or whatever. At the same time, I try not to let people walk over me...[or] come across as weak and helpless, you know [laughter]?"

\section{Playing traditionally feminine roles and doing the office housework.}

The survey found that only $8.0 \%$ of Black women reported pressure to play traditionally feminine roles, yet the interviews surfaced a number of women who did so. One Black mathematician noted that she's "kind of seen as this motherly nurturing person in the department." Colleagues often sent students who were having problems to her. "I' $m$ not a counselor, but I' $m$ the only female in my department. And I work with a lot of foreign faculty members 
who have expectations of women. And the expectations that they have is that, you know, women are supposed to be caring and nurturing and to take care of the kids." Another Black woman, a biologist, noted the expectation that women are a good fit for emotion work: "it's like, 'Yeah, you can tell me all your problems because that's my job sort of to help you solve your problems,' as opposed to coping with my own." She protested, "This is in the workplace."

The most poignant story was of a Black scientist whose mentors were "very adamant" that she didn't "need to sit on every blasted committee." So, in a meeting with the provost, she pointed out that Whites as well as people of color could be tapped to serve on diversity committees. The provost's response was to invite her to serve on another committee. "Of course I'm not going to say no to the provost. This is the man who basically has my tenure in his hands." Other studies have noted that women of color sometimes are more committed to "race-based service" (Baez, quoted in Stanley, 2006). Among our informants, the focus was more on how such service was extracted regardless of the wishes of the professor of color.

\section{Latinas}

Angry - or assertive?

An important finding of the survey was that for Latinas, much more than for other groups of women, expressing anger is a danger zone: $59.4 \%$ said they did not feel free to express anger at work (as compared with 54.5\% of AsianAmericans, $49.7 \%$ of White women, and $47.8 \%$ of Black women). The interviews also found that Latinas are often seen as angry when they're not: Latinas who behave assertively reported that they often were discredited as "angry" or "too emotional" even when they weren't angry; they just weren't deferential. In the survey, Latinas reported the lowest levels of pushback for behaving assertively (46.9\%), although Black women (54.2\%) and White women $(52.3 \%)$ were close. Still, almost half of the Latina scientists surveyed reported pushback for assertiveness and the interviews provided many examples.

Said an environmental engineer, "Everybody is afraid that I'm just going to start crying or that I'm just going to get really mad." She noted "a lot of fear that, the Hispanics and the Black women, we'll just blow in a meeting because we are so much more emotional and we cannot handle ourselves in the way that everybody else can." She had protested when a job candidate kept being referred to as the "minority candidate," she was told to "stop being so emotional about syntax.' And I was like I'm not crying. I' $m$ not raising my voice. I'm not doing anything. Why am I being emotional when I'm telling you that this is just simply wrong...." 
Again and again, Latinas reported being criticized as "angry" when they behave assertively. Said a Latina biochemist, "my department chair basically called me to his office afterwards and told me that I was giving the impression that I was an angry lady and basically encouraged me not to open my mouth and express my opinion during faculty meetings because people were going to think that I was just a hysterical woman." She noted that she had acted no differently than her male colleagues in expressing her views. Sometimes backlash came from students rather than colleagues. A neuroscientist recalled what happened when she asked a student to leave her lab because the student had been disrupting the smooth functioning of the lab. The student told her, "You're just too emotional. If you were just a little bit more cool-headed." The neuroscientist noted dryly that, "On the other hand there are some people that think that I'm just really too strict and too non-female-like."

Another theme was that Latinas were overly emotional or "crazy," a charge rarely reported by other groups of women. "I have found that it is much more accepted for a male to be aggressive," said a Latina engineer. "Many professors that will even kick the doors and everything, and nobody seems to care about that. I can guarantee if a female does it, they will feel that she's crazy." Said a statistician, "many times, when a woman has a dissonant voice, they are called, here and also back home, a crazy so and so."

Some of the scientists tightly controlled their emotional expression in order to avoid these stereotypes. "You have to be completely emotionless because that person's just going to say, 'Oh, she's a woman'" and see you as weak, noted a Latina in anatomy. A Latina biochemist recalled getting angry when someone did something she considered clearly inappropriate. "I was called to the principal's office to use a metaphor." She was "absolutely sure" that none of her male colleagues who got angry at faculty meetings got called on it.

\section{Latinas walk a Tightrope, just as other women do.}

"You have to thread very finely," said an engineer. You have to "speak up your mind" without making your male colleagues feel "emasculated. So it's fine thread." An aggressive style works for men but not women, said a Latina in clinical science. "A similar behaving woman would not be received with respect, more likely be denigrated."

Some felt expectations that women would be "soft," understanding, and "accommodating." "[I] have to be very assertive to be heard and sometimes people take that as aggressive," said a Latina immunologist, but if you're too feminine, "then they think you're not smart enough." "You have to walk a very fine line," remarked an engineer, "You cannot let them walk over you. Otherwise, you're not going to get anything accomplished." 


\section{Large loads of office housework.}

In the survey, about a quarter of Latina scientists (28.1\%) reported expectations that they play traditionally feminine roles such as office mother/dutiful daughter - considerably less than Asian-Americans (40.9\%) and White women $(35.9 \%)$ but much more than Black women $(8.0 \%)$. Yet the interviews contained many reports of Latina scientists expected to play traditionally feminine roles, including literal housework as well as emotion work and work typically performed by administrative staff.

The Latina scientists interviewed reported that both students and colleagues expected them to do office housework. A Latina bioengineer remarked that students expect women professors "to be more motherly and more willing to make exceptions for them, if they want to." Male colleagues could tell students to leave the classroom if they were not paying attention. "They can say things quite frankly, rudely, and people love them. They think they're great. If I said that I'd be crucified. They would think I was the biggest, most horrible witch there ever was." Both male and female students expected women to be supportive and nurturing. "They would never expect a male professor to respond well for example with them like breaking down crying in their office. I definitely feel that masculine/feminine gender roles, those expectations, I feel them on, yeah, a daily basis.... I'm pretty aggressive. I find that both men and women... are going to immediately... call [you a] witch. I'd use another word but it would be rude. [chuckles.]"

Latinas reported literal housework and admin roles never reported by other groups of women. A Latina bioengineer reported male faculty who "expected female faculty members to serve them tea or coffee or take notes." Noted a Latina in biomedical research, "They treat you like their mother, like they can get whatever you can from you, and there's no limit. Like, if you keep helping, they keep asking."

The most shocking example was of a Latina in clinical science who was literally treated as an administrative assistant. "I think there are times when I am asked to be kind of the mother of the group," she said. This included tasks like making sure everyone filled out their paperwork or setting up a meeting. "I play many roles that...could be done by a competent administrative assistant if we happen to have had a competent administrative assistant, which we don't." She had tried to get rid of these "administrative duties [that]...eat into my time," but without success.

Men have higher salaries, noted an engineer, but women are expected to do more service. An environmental engineer reported that male colleagues try to delegate "managerial tasks, making copies, making sure that everybody's going to be on the meeting." 


\section{Dress is an important issue.}

Many Latinas sensed a tension between the way they believe a woman should look and the dress expected of scientists. Respondents widely acknowledged that scientists are "normally blue-jeans-and-sneakers people." Non-Latinas tended to notch that dress code up a bit and call it a day. But Latinas often felt caught. "You're expected as a scientist to look a little scruffy and not well taken care of," said an immunologist. Note the conflation of feminine dress and being "well taken care of." Lamented a biomedical researcher, "So if you dress well, you get less respect."

Just as Asian-American women struggled to reconcile the pressures to self-promote with the cultural mandate to be modest, Latinas struggled to reconcile cultural mandates of feminine dress with dress norms in science. A biochemist nailed the dilemma: "You are kind of exotic." She had to "tone down" a lot so she is perceived as "culturally neutral" when she presents her science. "...I don't want them to be distracted by my earrings or by the loud print in my shirt or by my hair or whatever."

A neuroscientist said she tried not to wear too much makeup because "I don't want to be perceived as less than knowledgeable about what I do." An engineer recalled trying to look more masculine in the classroom in order to establish her authority, given that other signals (she felt) undercut it: that she was only 26, petite, and had an accent. "I would wear always pants, pantsuits just to try to assert a position out of fear that nobody would see me as a figure that they could respect."

Latinas who didn't eschew highly feminine dress often were counseled to do so. When she moved institutions, an engineer said, her dean took her aside and told her to dress more professionally. "So it's really difficult, because if you dress the way that you want to dress, you stand out."

Another engineer's advisor coached her for a job interview by telling her, "'You don't want to wear a pink...flowery dress... wear a nice dark-colored pantsuit." Several other women had received similar advice.

Other women stood their ground and made their refusal to conform a point of pride. "I cannot make them stop thinking about, let's say, the color of my shoes," said a Latina in biomedical research, "because they're checking them out as they're talking to me, and that used to annoy me a lot. But, I just ignore it and I just keep talking about my science." "I will dress in the way that I feel comfortable, because if I' $m$ dressed in a way that I'm not comfortable, my whole game is off," an environmental engineer remarked.

Even women who refused to compromise on clothing made allowances. The environmental engineer was careful to wear "nothing revealing, nothing tight, because I'm very careful because, Hispanics especially, we like tight clothing. So I'm very careful to always look for clothing for work that's not overly tight, that is not revealing." A biochemist noted that, in Mexico "it would be pretty common that we wear tight clothes and...miniskirts, and I 
don't do that here because...I wouldn't be considered a serious scientist, or my message would be lost."

Some Latinas used feminine dress to create room for themselves to behave in highly valued masculine ways. "I happen to be a very girly girl," said another engineer. "I like high heels, I like cute dresses. Actually, that makes me stand out at conferences. I don't try to dress like a man with the pants and the pantsuits and that kind of stuff. I never do that. I don't own a single pantsuit." She felt that, for the most part, her style was received positively. She was very outspoken, she said, and "aggressive, using the word that men use; but what you see doesn't match." She'd been told she was a contradiction, and "I think that actually has been a positive thing in my career, because I surprise people. It's actually a good thing to surprise people, they remember you." This is gender judo: doing a masculine thing (being assertive) in a feminine way (in a stylish dress). It's a common strategy women use to defuse backlash against masculine behavior.

\section{Performing gender judo.}

Latinas were much more explicit about gender judo than were women of other groups. An environmental engineer recalled her mentor warning her that "trying to be the man didn't work because people immediately - you immediately get called the bitch." Her mentor recommended gender judo: "she just started using her charm in the way that she talked to people, smiling a lot, and she became a lot more of herself. And I tried - and that really stuck with me."

An engineer reported being told, "you're very assertive in a very sweet way.' I get what I want in a very sweet way....Doesn't antagonize anybody." Note how she does a masculine thing (being assertive) in a feminine way (being sweet). Another Latina said that when she needed to be assertive, "I try to do it more in a calm, firm way. I actually think that's worked really well for me." A statistician agreed, telling her younger colleagues that they needed to "be pleasant but firm."

A bioengineer noted that, particularly with older men, one has to be careful "you're not so aggressive that you'll completely shut them down." Her solution was to downplay her ambition, and instead present herself as more communal - one of the team. A statistician agreed. "I try to do it sweet and polite, but I make my point and I say what I think... When you are a woman, you have to do that. If not, they will walk over you with heavy boots." "There are smart ways of being assertive," concluded a biochemist, "and not-so-smart ways."

One particularly astute woman in geography articulated the strategy Professor Deborah Gruenfeld calls "playing high" and "playing low" (Gruenfeld, 2013), using a stereotypically feminine demeanor when you are with people higher in status, and stereotypically masculine demeanor when you are with 
people lower in status: "I am really careful about the way that I present myself and my image," she said. "The way I present myself changes depending on who I'm meeting with." When she's meeting with high-level university officials, she barely talks and acts "shy and respectful. And I'm very clearly like the subordinate person in the room. But then in other meetings where I' $m$ more familiar with people or I' $m$ in more of a leadership role, then I would act a lot more direct and authoritative. But, at the same time, I'm still known for always being like really nice and someone who sort of comes up with little jokes, is fun at meetings."

\section{Maternal Wall}

Experimental studies show that the maternal wall, once triggered, is by far the most damaging form of gender bias. The most famous study gave people identical resumes, one but not the other a mother, and found that the mothers were $79 \%$ less likely to be hired, only half as likely to be promoted, offered an average of $\$ 11,000$ less in salary, and held to higher performance and punctuality standards (Correll, Benard, \& Paik, 2007). Other studies (Benard $\&$ Correll, 2008) have confirmed that motherhood not only triggers very strong negative competence and commitment assumptions; mothers also walk a tightrope: if they are seen as indisputably competent and committed, mothers tend to be disliked and held to higher performance standards by women (although not by men) (Benard \& Correll, 2010). Evidently, women often see mothers who work long hours as bad mothers - and therefore as bad people.

The survey measured one form of maternal wall bias, and found that Black (7.7\%) and Latina (9.1\%) scientists who were mothers were far less likely than White $(26.0 \%)$ and Asian-American mothers (26.7\%) to report that their colleagues had communicated that they should work fewer hours after their children were born. For Black women, this finding may reflect the stereotype that Black mothers should work rather than stay home with their children (Cuddy \& Wolf, 2013). All groups tended to attribute Maternal Wall problems to gender.

Maternal wall bias affects non-mothers too. One study found that women without children encounter the highest level of general workplace harassment of any group (Berdahl \& Moon, 2013).

Whereas mothers may well be seen as good mothers but uncommitted scientists, women without children often are seen as somehow lacking as full human beings "without a life" (Cuddy \& Wolf, 2013; DePaulo, 2006). This may explain why women without children work the longest hours of any group of workers (Trades Union Congress, 2008). Asian-American women $(34.5 \%)$ were far more likely than other women to say they felt they needed to spend more time working to compensate for the schedule of other col- 
leagues who are mothers, followed by Latinas (23.8\%). Black women (15.4\%) and White women $(13.6 \%)$ were far less likely to say this.

There's a stigma against scientists who have children and a different stigma against those who don't. In terms of its impact on the careers of women in STEM, motherhood is a no-win proposition.

\section{Asian-Americans}

\section{Negative competence and commitment assumptions.}

"I feel like people think that Asian woman, they are caring and then they will give up their professions for their children," said an immunologist. Said another Asian-American, "I have to fight very hard to show that I am good scientist as well as a good mother." "People do judge women who have kids," said another Asian-American immunologist, and there's "this perception that if you're a mother, you can't be a high-achieving scientist," although she thought this was changing fast. Other women did not note progress. "You can either be perceived as the nurturer or extremely competent, but it's pretty hard to be perceived as both," noted a chemist. An Asian-American soil microbiologist put it slightly differently, saying you can either be "the superscientist" or the "supermom," but not both. An Asian-American physicist described the sentiment that "if you had a full blown career, that's inconsistent with being a mother."

Women in STEM often are competing against men with stay-at-home wives. An immunologist noted this, but also said that the full professors with daughters were "actually a little bit more sympathetic because they tended to have daughters who were going through the same thing." A soil immunologist found the most support from her administrative assistant, who was very supportive when she had to cancel class or a meeting "because she's been through it and she is going through it."

Mary Ann Mason and her team have documented that the largest leak of women out of the STEM pipeline is when they start families (Mason, Goulden, \& Frasch, 2010). Women in graduate school are anxious about how they can become both scientists and mothers, said an Asian-American statistician. Upon learning she has a child, students ask her questions like, "Is it possible to have a kid and be an academic? Is it better to have a kid while you're doing your Ph.D. or when you're doing your post doc?" This happens, typically, with students from other departments where all of the advisors are male. She mentioned a colleague in biology who said that, after the birth of her first child, "the floodgates opened and all sorts of female grad students and post docs would come talk to her about this, because this is something that nobody talks about very openly."

The irony, said a microbiologist, is that it's not true that mothers can't succeed in science. She felt that mothers "are actually more productive 
because they have a set schedule. They have to come in at a certain time because, at the end of the day, they have to leave and go pick up their kids. So they're a lot more organized. They're a lot more efficient... They are very selective about the meetings that they go to and get the most out of that meeting." Many others mentioned that scientists who are mothers often are more focused and efficient than their colleagues.

When it comes to motherhood, the U.S. "mindset is kind of more backward than other country," said an immunologist originally from Taiwan, where, she noted, children are in school until 5:30 in the evening. Because the educational system is not set up for working mothers, she said, a lot of highly educated women have to give up their jobs in order to educate their children.

\section{Support from their families.}

Women from India and China discussed how their mothers supported their careers, and encouraged them to continue. When the immunologist was thinking of quitting, her mother urged her not to, reminding her that her children would grow up, and lauding her for "trying so hard to hold on to your dream and if you give it now, you might never get it back." She persevered. A geophysicist discussed having to live on a different continent than her husband when her child was a toddler. She felt judged by both by Europeans and by some "Asian mothers themselves saying that, you're an Asian woman, we give priority to our children and family, how can you just leave your husband and be here." It hurt, she said, "I didn't know what to say, and I didn't have the energy to fight these comments. I would come back, and it would make me cry." But her own mother reassured her: "That's why you're different. You go ahead in life. Don't bother about them. Not everyone has the smarts or has the sensitiveness, and you can't just teach everybody, just move on." She did.

\section{Pink-collar ghetto.}

Most of the women professors interviewed were tenure-track, but a biologist who was not highlighted the perils of the "trailing spouse": "you got hired on the soft money, and they start forgetting the promises, and you find...you are stuck..." She felt cheated and angry.

\section{Family care extends beyond children.}

A geophysicist highlighted that minorities are more likely than other Americans to have family care issues that extend beyond children. "I think a lot of professors don't realize that often the successful minority student is the most successful person in their entire family, and they have to take care of everybody else." Their caregiving responsibilities can extend to "aunts and their uncles and their grandparents and their parents and their brothers and sisters and their brothers' and sisters' children, because even as a grad student, they could be making more money than anybody else in the family." 
A bright spot: one biochemist's experience shows that motherhood can fit well with science. Asked whether she had hit the maternal wall, she responded, "I've never experienced this." A single mother for over a decade, she has had a very positive experience: "everybody who meets me always congratulates me on how wonderful daughter I've raised and how well accomplished I am in my field and something that I've always got accolades on, both for my daughter and for my career... [N] one of my faculty advisors have restricted me in bringing my daughter to the lab, you know, have a little office, and she could sit with me as long as I was working. I was allowed to work from home any time. So, yeah, I got it really lucky in the last seven years on that front." It's not impossible to combine science with children; one only wishes more environments recognized that.

\section{Black Women}

\section{Negative competence and commitment assumptions.}

A Black microbiologist noted that she would never admit it if she had to be absent to care for a family member because to do so might be seen as her being "weak" or noncommitted. "[T] here is an assumption," said a Black microbiologist without children, "that your career is more of a hobby than a career, and you're only going to do it until you find a husband and/or have a family. It's not taken as something that's serious. You're taken as more of a passerby on your way home to be a wife and mother." A Black statistician recalled that a colleague came up to her and told her she should be at home with her child. A Black biochemist remarked that women "always want to get their job before anybody notices they're pregnant. I was like, why would they do that? Because it lowers my chances of getting the job." A Black microbiologist said that maternal wall bias played a role in her decision not to have children: "Yes. I was aware of it as early as high school, which is why I decided as an adolescent never to have children."

Some Black women encountered race-specific stereotypes. A microbiologist stated that, while "I don't have any data, being a Black woman with children gets complex because the assumption is once you start, you're never

going to stop. You'll end up being a welfare queen. So I also didn't want to deal with that."

\section{Hostile, and benevolent, disapproval of working mothers.}

A Black microbiologist reported that a colleague had been told that "she should go have little babies, she should go home." Similarly a Black mathematician recalled women students came to her disturbed when a male "professor told them that they shouldn't be in this class, that they should be at home having babies." 
In addition to this "hostile prescriptive stereotyping," some also reported "benevolent prescriptive stereotyping," through comments that again send the message that good mothers belong with their children - but in a different tone of voice. One Black woman recalled a colleague saying, "Wow, why are you here so early? You should be home with the baby." She found herself "almost trying to explain to him, 'No, no, no, it's okay. The baby is with my mother-in-law. She's with family." She later learned that his wife had stayed home for the first year of his child's life. When a supervisor believes that mothers "can't do it all," noted a Black doctor, that becomes a selffulfilling prophecy. She recalled a colleague who ended up going part time because the chief in her department was "insensitive to that need of trying to be a parent and a full-time employee."

\section{Maternal wall for women without children.}

While women with children definitely reported bias against mothers, women without children felt disadvantaged, too. A Black woman in microbiology felt that, although she didn't want children, "it's something that individuals are dying to know, because it's almost, like you say, they're ready to hold it against me." She recalled a Black colleague asking her, when she described her job, "How can you do that? Doesn't your husband want babies? Your husband will never get babies with you doing all of that." "I just looked at him and said, 'Doesn't your wife want to do something other than have babies? She's pregnant every time I see her." She was told her salary was lower than her male colleagues' because they had families to support. "The biases are there," she concluded. (Note that this is illegal sex discrimination.)

\section{Family-friendly policies and the flexibility stigma.}

Black mothers, unlike those of other groups, discussed the family friendly policies - and lack of them. One scientist noted that her institution's lack of clear policies for how to temporarily replace women on maternity leave left her "scrambling." Others highlighted the "flexibility stigma" - the stigma often encountered for use of stop-the-clock policies (Williams, Blair-Loy, \& Berdahl, 2013). Said a Black statistician, "other people felt like they were doing me a favor and I'm like 'You're not doing me a favor!' [Laughs] 'This is just, this is the policy right now." You have a legal right to leave under the Family and Medical Leave Act, she observed, whereas "other people will try to make you feel like they're doing something special for you."

Several women felt pressured not to use their institution's family leave policies. A Black electrical engineer recalled a colleague who almost decided not to stop the tenure clock. "But it is something that is clearly stated in the rules, yet in practice, most of the female faculty that I've spoken to and some of the male faculty did advise me against doing it." Note that this kind of 
advice can easily be seen as illegal interference with Family and Medical Leave (Family and Medical Leave Act of 1993, 2006).

A Black statistician noted that some of her colleagues did not use her institution's stop-the-clock policy. She believes they chose not to do so because they do not want to appear "weak" or as though they are receiving "special consideration." The same woman recalls she was admonished by her doctor for her reluctance to ask for maternity leave. Her doctor told her there was no explanation for her health issues "other than stress."

The tragedy is that it's so easy to get it right. A Black doctor recalled how worried she was when she had to tell her supervisor she was pregnant. $\mathrm{He}$ surprised her: "he's actually very sensitive to the female faculty and the fact that we have children." He thinks the tenure clock is "stupid," she noted, because it penalizes women when they want to have children. "I think he's an anomaly. [Laughter] but he actually gets it... Part of it, his wife is a physician, so I'm sure she's probably beat him over the head and grilled some of this stuff into him, which is probably a good thing."

In another hopeful story, a Black statistician who was "initially very fearful of sharing the news with my department" also found a supportive response when she finally got up the nerve to tell her department chair. He asked why she stopped by and "I' $m$ literally stuttering through the statement saying that I just wanted to inform you that I won't be able to participate with the summer program this summer. In my mind I' $m$ watching his face drop when I say this. Then I conclude, 'Because I'm expecting. Because I'm pregnant,' and he lit up. Mind you, this is male chair, right? He lights up, he gets - he's so excited. 'Oh, I'm so happy for you.' I was actually in shock that he responded like this because I had braced myself - ironically enough I was more prepared to face a backlash than a happy response, right? I'm just standing there a little stunned and taken aback and like oh, okay [laughing]... my son was basically the department baby."

STEM would lose far fewer women if more department chairs reacted in this way.

\section{Latinas}

\section{Negative competence and commitment assumptions.}

Many Latinas reported maternal wall bias. "If you want to have a family," said an environmental engineer, "people do put in question how much you want your career." A Latina bioengineer's advisor told her, "Well, I don't want you to get your Ph.D.; you're just going to get married and have kids." She reported she was "basically told to leave" when she had a child as a post-doc. Sometimes the comments may be subtler, "like, 'I called them, but they're never in their office,' or 'They won't be here after a certain time of day," said a woman in anatomy. 
More subtly, a Latina who runs a lab recalled that, after she had a baby, colleagues related to her as a mother rather than a scientist, "they thought that there was nothing that they could talk to you other than, 'Oh, how's your son?" She recognized that they meant well, "But, I have lots of other things to talk about."

Even some women without children reported maternal wall bias against colleagues with children. A biologist recalled "Some guy saying he was not going to hire a female research assistant because it's likely that she was going to get pregnant and then he'll just have to find for maternity leave and those things." One year, noted a Latina engineer, "a lot of men especially started taking me a lot more seriously because I was the single woman, gung-ho, very career focused. So I was taken very seriously by men." An engineer spoke of a colleague who returned to teaching three days after a Cesarean section because "I don't want to be perceived as not doing my job because I have a kid.' I said, 'But you just had a C-section."'

\section{Hostile disapproval of working mothers.}

Assumptions that mothers were not committed were matched by judgments if they were: A biomedical engineer reported, "many people say...I would never let somebody else...raise my children as if like our nanny is raising our children."

Some mentioned a double standard for mothers and fathers. A Latina biologist noted that when men said they had to leave to pick up their children, "people will stop and say, 'Oh, you are such a great dad. That is so wonderful that you spend time with your kids." The reaction when women did the same was very different.

\section{Bias avoidance.}

The pattern of bias avoidance (Bardoel, Drago, Cooper, \& Colbeck, 2011) documented by Robert Drago and his colleagues emerged in a comment by a Latina engineer who said she had decided, for now, not to have children because other women in her department did not, and the wives of the male faculty "are not working mothers, they are at home taking care of the kids." Of course, if young women feel that they will not be able to have children if they choose science, fewer will choose science - that's a price male scientists don't have to pay.

\section{Family pressures to have children.}

In the survey, $69 \%$ of both Latinas and Asian-Americans described pressure from their families to have children (as contrasted with 60\% of Whites and $31 \%$ of Blacks), but family pressure to have children emerged strongly only in the interviews of Latinas - especially Mexican-Americans. Said a Latina biochemist, "Every good Mexican woman has kids in their 20s. Like I told 
you, I'm not following the norm with my culture. I address that like anything else. It's like it's my life, I will have kids when and if I want them." The notion that traditional Chicano/Mexican culture "Places a higher premium on motherhood" has been noted in other studies of women of color in academia (Stanley, 2006).

Other women received the message not only that they should have children but that they should not have careers. Said a Latina bioengineer, "Family is extremely important. Achieving for something higher, at least in my case, it was seen as a waste of time. 'Why are you pursuing graduate school when you should be working?' or 'Why are you pursuing graduate school when you have a husband to take care of?" Others faced expectations that they would shoulder all or most of the family work. "[B]eing a mother I think goes across all cultures," mused an immunologist, "and it's just a challenge for all. In terms of being a Hispanic mother...our culture expects women to definitely be the primary caregiver....99 percent of the work was my responsibility." A Latina doctor noted, "I feel like I have a very specific role in keeping my family running," a pressure she saw as self-imposed.

Once again there were happy stories. A Latina engineer who found out she was expecting shortly after she accepted her position found that her "colleagues are extremely supportive. I bring my child three times a week into my office. I take her up to the lab when I need to, you know, set up stuff. Nobody - if I need an extra pair of hands, somebody will knock on my door, one of the guys, and said, 'Oh, let me hold the baby for a little bit."' Because of the support from her colleagues, she felt no need to stop the tenure clock. She took six weeks of maternity leave, and was encouraged to come back slowly. "So, I really - I have had a very, very good experience so far."

A Latina biochemist had a similar experience. "[M]y employer is a fantastic employer... As an institution, they get it that...women have a right to have babies... [and take] maternity leave." Noting that her department chair is a "family man," she said he set the tone for the rest of the department. When she had trouble with a nanny who did not arrive as planned, "...he basically said, 'Just do what you need to do to take care of your baby."'

Several Latinas expressed concern about losing a lot of women scientists because they are pushed out after they have children. Said one, "you're just losing a lot of people that eventually will probably still even go back to putting in like even more time later on. I don't know if that makes any sense." Latinas, like women from other groups, pointed out that the mothers they knew had become more efficient scientists since they had children.

Again, a simple way to keep women in STEM is not to drive them out after they have children. 


\section{Tug Of War}

"Female rivalry in the workplace may sometimes be as important as sexism in holding women back in their careers," opined an article in London's Sunday Times (Dobson \& Iredale, 2006). But female rivalry is often the result of sexism. Two 2011 studies found that a common strategy for women experiencing gender discrimination in the course of their careers was to stereotype, distance themselves from, and criticize, other women (Derks, Ellemers, van Laar, \& de Groot, 2011; Derks, van Laar \& de Groot, 2011).

An important proviso: by discussing the gender dynamics that set women against each other, we are not saying that women never support each other. As has been noted, three-quarters $(75.5 \%)$ of the scientists surveyed reported that the women in their environments supported each other. Nor are we saying that women should support each other every single millisecond: to say that would be to enforce the prescriptive stereotype that women ought to be endlessly selfless and communal. Men don't always support each other, and when they don't, the immediate assumption is not that they have personality problems.

Instead our contention is that women's workplace disputes over gender play a much larger role in complicating office politics for women than do men's disputes over gender with men. The reasons for this are complex, and it's the bottom line that's important - gender bias against women often fuels conflict among women.

The survey results highlight the complexity of this phenomenon. Although three-fourths of the scientists said that women support each other, Black women $(56.0 \%)$ were far less likely than other groups of women to agree with this statement (70.5\% of Asian-Americans, $76.9 \%$ of Whites, and $78.9 \%$ of Latinas did).

In addition, when asked more specific questions, patterned conflicts emerged. One is a pass-through of Tightrope bias. As women walk the tightrope between being seen as too masculine and too feminine, they may end up judging each other for failing to achieve the right balance. Roughly half of the scientists surveyed agreed that "some women have just "turned into men." Once again answers differed markedly by race/ethnicity. AsianAmerican scientists were far more likely $(70.5 \%)$ to agree than were other groups (50.0\% of Latinas, $48.8 \%$ of Black women, $42.1 \%$ of Whites).

Maternal wall bias also can be passed through from woman to woman. Thus $41.7 \%$ of those surveyed agreed that "some women just don't understand the level of commitment it takes to be a scientist." This pattern differed less by race/ethnicity: $42.1 \%$ of Whites, $38.6 \%$ of Asian-Americans, $37.5 \%$ of Latinas, and $36.9 \%$ of Black women agreed.

Another Tug of War problem is when women professionals find it difficult to get administrative support personnel (who are typically women) 
to do their work. This may occur because support personnel feel more comfortable pushing back against women than men, or because support personnel perceive men as having more power to help their careers, or for other reasons. "I have heard administrative assistants say that they would not want to work with a woman boss - because they're harder to work with - which I thought was astounding," remarked one scientist. This was relatively rare overall: only $18.2 \%$ of women reported it as a problem. But Latinas were far more likely $(35.5 \%)$ to report it than were other groups (20.5\% of AsianAmericans, $16.9 \%$ of Whites, and $15.4 \%$ of Black women). The interviews suggest this combines racial and gender bias: One scientist was very aware of the racial dynamic involved, saying "conscious or unconscious," there is resistance based on the fact that "there is this Mexican woman telling them what to do."

A final pattern is tokenism, where women are forced to compete with each other for the one "woman's spot." About a fifth (20.6\%) of scientists surveyed reported this, but the incidence varied a lot by race. About a third of Black women (32.0\%) and Asian-American (29.9\%) women reported this problem, as compared with lower levels among Latinas (21.9\%) and Whites $(17.3 \%)$.

Some women reported no Tug of War because there were too few women in their departments. Said one, "It's probably because, in engineering, there are very few women, and it happens that I most of the time was the only one." An engineer agreed. "So I don't think we have enough females in the department or the school for such patterns to happen," she said.

\section{Women often support each other.}

First, the good news. Said a Latina biochemist, "the women in my department and especially the women doing science here in my institution, we are really - we bond together. We support each other a lot. If anything, I've gotten a lot of support." "I've been very impressed at my current workplace of this solidarity among women," said another Latina scientist. An AsianAmerican pathologist said, "[T]he women faculty I met that older than me [are] always very encouraging, very helpful and very kind to me." An AsianAmerican geophysicist agreed: "I've had senior women administrators been so supportive with me that I have just good feelings and good thoughts about that."

An Asian-American soil microbiologist spoke of how supportive other women were when her daughter got sick "for quite a long time and so I actually ended up getting behind in my research. Whenever I would sort of go into this panicky mode of ' $O$ h my God, will I ever go back to writing papers?' - I actually had a couple of senior colleagues elsewhere who [were]...incredibly supportive. One of them very clearly said 'You know, right now you take care of your kid because she's sick. Just remember that 
way back, you knew how to do a Ph.D. so you know exactly how to write papers. It'll happen.",

Nonetheless, the interviews and survey also reported several classic Tugs of War.

\section{Tokenism.}

A fifth of the scientists surveyed $(20.6 \%)$ reported "I feel like I am competing with my female colleagues for the "woman's spot." Tokenism often fuels conflict among women, as politically savvy and ambitious women vie for the woman's spot. The three other types of gender bias also can fuel Tugs of War.

\section{Prove-It-Again pass-through.}

Older women who have had to prove themselves over and over again may hold younger women to higher standards than men. An Asian-American woman in statistics described an experience told to her by a woman colleague: "I did not know the older senior female scientist personally, but as we talked it became evident to me that the older woman scientist probably had to go through hell to get to where she was - you know to get to her senior position. Since she had had to go through hell, she wanted to make sure that everybody else had to go through hell." As a result, she said, her "junior scientist was just having a horrible, horrible time of it."

\section{Pass-through of Tightrope bias.}

If the Tightrope often requires women to balance the masculine and the feminine, women may be divided by different balances. An Asian-American described a colleague who "was very much the 'I will bake cookies for my students, I'll pick up everyone's plates after a lunch."' Her colleague asked her, "'Well, how can you leave your baby at home?' It's like 'Well, I work. I don't think babies need to come to the Statistics Department.' [Laughs] I have colleagues, I mean, we all had kids about the same age, but they were never questioned about 'Was it okay for' - you know, so somehow I wasn't being feminine enough by actually just coming to work. [Laughs]." Note how the more stereotypically feminine woman judged her colleague for making the wrong balance between being too masculine and too feminine. Survey participants suggested this is common: $51.4 \%$ agreed that "I feel some women have just 'turned into men,' assimilating to the way men run their careers and their lives."

In addition, sometimes women expect other women to shoulder the kind of office housework that is rarely extracted from men. Said an AsianAmerican, "I feel that female leaders can be as bad as a male leader in terms of gender bias." Her female boss expected her to edit her grant, a "secretarial job....And I'm sure that she will not ask men to do that." This may be driven 
by stereotyping - women are expected to be helpful - or it may simply reflect that the leader sensed the political reality that asking a man to do this kind of work might be politically more costly than asking a woman.

\section{Mommy wars.}

Because mothers and women without children encounter quite different types of maternal wall bias, it's not surprising to find women judging each other around issues related to children. On the one hand, mothers may resent nonmothers on the grounds that they have it easy. On the other hand, nonmothers may resent mothers for getting "special treatment" or for reinforcing stereotypes that women need special treatment.

One scientist recalled conflict over a women's group when another professor said "'Well you just don't understand because you don't want kids, and that's not your plan.'...I was a little flabbergasted....I don't think a women's group is synonymous with a mother's group. I felt like perhaps she was angry at women like me."

Mothers who feel judged for being mothers may sense that it's less risky to express anger at other women than at men. At a simpler level, the harsh fact that women of all races are often under hydraulic pressure to have children may make women who don't want children very emphatic. For all these reasons, gender bias against mothers turns into conflict among women.

Conflict between women scientists and their female bosses and students. "Immediately," said a doctor, "the male doctor gets more attention than the female. And it's sad that it comes from other female administrators and the non-professionals in the system...that does occur a lot." A grad student reported colleagues who said they did not want to work with a woman: "I've also heard females say things like 'I want a male boss.' I' $m$ like, why do you want a male advisor? It makes no sense.... [T] hey have the feeling that well maybe [a female advisor is], I don't know, they call it PMS, or something? That if she's going to take it out on them, that they are always very moody and stuff like that. It's a female thing.... It's, I don't know, even within ourselves, I still see the bias." Years of studies document that it's not only men who stereotype women. Women do, too.

\section{Asian-Americans}

\section{Tokenism.}

Many Asian-American women reported the tokenism effect. One AsianAmerican in biophysics pinpointed precisely how tokenism creates conflict among women, saying that when "each department wants to have a female faculty" a department with two women will find themselves pitted against each other: "one female will be the one to stay, the other one will not. And I 
have seen that kind of situation." An Asian-American doctor pointed out that, if there were only one "man's position," men would behave the same: "they'll fight to death among themselves to reach the top. So why shouldn't a woman do that?" Said an Asian-American scientist, "Oh yes, the notion of there's only room for one, I face it very, very actively. As I told you, when I was hired, I was hired along with this older woman at the same position. And yeah, she still hasn't given up. We both got tenure. She tried to block my tenure. And also, there's a premium for being the first X, right, woman, first woman blah, blah, blah. And the minute there's another woman coming along the pike, you feel that you'll be displaced from this position of being like the first tenured woman or whatever, right, if you're a senior older woman. We try to take it for granted that women will help us, but they almost never do. Why is that?" If there's only room for one woman to succeed, undercutting the competition is a logical response.

Another Asian-American offered a slightly different theory, saying that she felt some of her female colleagues are "conflicted." On the one hand, they want to help younger women. "And yet, at the same time, they don't want to lose their...power positions." Her approach was to acknowledge that she wouldn't be there absent the efforts of the older women: I "remember to thank them and remind them that, without them, I wouldn't be here. I wouldn't have made it. So I'm continuously humble." She noted "it's the same in general when... you express respect and gratitude to your grandparents or even your great-grandparents if they are still alive. You have to recognize what they had to go through and appreciate what they had to go through in order for you to have what you have today." Here the Asian tradition of respect to elders clearly had served her well in defusing potential conflict.

Another Asian-American described a situation where she and another woman of color, somewhat older than she, joined their department at the same time: "Intensively competitive because of that, because she always felt she needed - she should have a higher salary because she has more experience." Studies show that women tend to compare their salaries with other women's rather than men's (Buchanan, 2005).

In addition, the tokenism effect can fuel conflict among women when White women attempt to deploy their racial privilege to cushion the effect of gender bias. One Asian-American described situations where "women would deprive me of information or resources that I'm entitled to... I' $m$ a person of color, they felt it was easier for them to try and undermine me."

An Asian-American geophysicist clearly recognized that the tokenism effect disappears when women are no longer tokens, saying "you reach this tipping point where there can no longer just be one spot, that there's not a quota, we have to have our token woman, and then you want to be that token woman - where sort of having them around is just sort of more normal, it's 
not an oddity. And when you get to that point, then the competition goes down because you're not fighting for that one position."

\section{Tightrope pass-through.}

A self-aware Asian-American physicist noted that "it does seem like there is a tightrope of not too feminine, not too masculine." She noticed herself "wincing when some [undergraduates] seem in my mind a little bit more feminine than I would feel professionally comfortable with. On the other hand, I'm happy that they feel comfortable being the way they are."

\section{Prove-It-Again pass-through.}

"I know women can be very prejudiced against other women and if one woman is in a higher position and could be super critical of other women and wouldn't support them," said another Asian-American. "They're harsher to women in some cases. Well, I think there are several reasons behind that because the person at the top could be there because she struggled a lot and had to work extra hard and so expects other women to have done as much as she has." Another scientist agreed that sometimes happened. "I was very much encouraged because I had a woman mentor." In fact, she noted, that's why she went into her field. "But, I have seen how other - sometimes, it's other women harder on other women... 'Well, I had to fight my way to the top. You need to do that, too, on your own,' attitude."

\section{Mommy wars.}

A simple, straightforward reason that resentments arise between mothers and women without children is that the latter often feel they get work dumped on them by parents. Said one Asian-American scientist, "People immediately assume that because I don't have children that I should be the person who takes our colloquium guest every Thursday when we have a colloquium to dinner, that I should be there as the faculty member, because they all have their wives and their great husbands and their children to go back to, and someone who's single basically can be called upon to do this all the time...."

Other Asian-American scientists without children described resentment by mothers. Said an Asian-American, "[T]he older White women, for them they can't handle the fact that I am single, living it up." Said another, "I don't want to get married to some guy, some random guy, and have 2.2 children because that's what everybody does. And until I meet somebody I really want to be with, I don't. I'm not interested in buying a house and settling down. And so, I live in apartments and I just have a single lifestyle. And that annoys all these women no end." Do they make snarky comments, asked the interviewer? "Oh, totally."

Note how the mothers judge women without children. Another woman recalled when a female colleague "opined that the university is full of these 
super ambitious women like you who are so focused on their career that they don't have a concept of family. It has all passed them by and that's why we have not had childcare here, because the university is filled with powerful women like you,' a really backhanded way, 'Powerful women like you who just don't care." She continued, "Everybody came up to me afterwards and said, 'My God, you had so much poise when this woman attacked you.' This woman didn't even realize that she attacked me. She didn't even apologize." She continued, "There's an enormous amount of resentment at women who, like my generation now, are actually making a choice to be single. We are not left on the shelf because we wear thick glasses and we are unattractive and we can't find any man. We are making a choice that, 'You know what? I don't like this traditional marriage thing. I don't want to do it. I am not sure I want to have children, so I'm - my clock isn't ticking. And if it's ticking, I'm not listening." She continued, "I have had many senior women come up to me and say, "You should have children. It's very selfish to not have children....' [S] he was trying to figure out if I was lesbian. It's just unbelievable."

This dynamic is further fueled when women have eldercare responsibilities that they don't feel are given the same deference as childcare. Said one woman, "Because women like me who don't have children, we have extra burdens. Like we have more responsibility on average. We're taking care of our elderly parents, right, because we are the single people in the family. Everybody - siblings are married and whatever, and those things - eldercare often comes on the plate of single people. I don't fit. It makes me feel acutely uncomfortable because I'm not interested in school districts. That's all they want to talk about. I have very little in common with most of these people."

Other women stressed generational divides. One senior Asian-American noted how tricky it is for women of her generation to give advice to younger women. Sometimes, she noted, "advice from us are not appropriate. Times have changed." For example, she noted that she had children later in life, but today you "can start a family almost any time. Just have to work out the problems and work out the situation. And - but, sometimes, I still tend to think, 'Don't have a family that soon,' but then I realize that may not be a good advice to the younger female faculty anymore."

\section{Black Women}

\section{Tokenism.}

Black women were much less likely than other women to feel that women in their environments supported each other. In the interviews, there was less talk of tokenism, and what there was concerned conflicts based on race, not gender. One Black woman noted that sometimes there was a dynamic by which Blacks were forced to compete because there was only room for "one 
'chosen' one." Another described a senior woman who, "when she's speaking, she pretty much focuses her attention on the men.... So I'm thinking she might be one of those types of women where, okay, there's only room for one." She noted, "it's been a survival tactic on their part how to survive in a male dominated environment. And so they probably are not even conscious of what they're doing." Said another woman, "It was challenging to sit on that committee and have other women discredit what I had to contribute because I was a junior faculty member, because I was the only African American on this committee, and because I was coming from a historically Black institution. And so, they have stereotypes about that, too."

Tokenism also led to generational conflict. A Black microbiologist found more senior women discouraging her from trying to excel "because it wasn't going to do any good. It's kind of like, 'You're a Black woman. You're only going to get so far, so don't worry yourself out trying to go further than that." This is another very pure example of how gender bias against women fuels conflict among women.

\section{Prove-It-Again pass-through.}

A Black scientist noted that, when she initiated a conversation, a female colleague "told me that it wasn't fair that I was allowed to apply for a promotion" early, and that "I should go through exactly what she went through in order to earn promotion. And she had an awful experience." Another Black scientist described "a female colleague, and she is much more feminine than I am in terms of those stereotypical behaviors. When she fails to get something done or she repeatedly makes the same mistake over and over again, it's dismissed. Oh, that's just her, she needs somebody to take care of her.... But, when I do something, I'm definitely held accountable for any minor things that are not absolutely correct. And people get really upset and angry." Notice one woman's strategy to immunize herself against Prove-It-Again bias by presenting herself as very feminine.

\section{Tightrope pass-through.}

A Black biologist was very self-reflective about how her advice to a student to "man up" may have reflected the Tug of War. "I remember having a graduate student that we worked together on our $\mathrm{PhD}$ and that she more so had I guess those traditional female qualities that if would say, you know, kind of very passive or very soft spoken if you want to say. And then, she cried a lot. And I remember I would always tell her, you need to man up, you know, stop all that crying, because they are going to keep walking over you and keep criticizing you on your research and your papers and things like that if you don't stand up and take charge.... Probably I could have told her in a different way." 
A Black doctor interpreted White women's insistence on empathy through a racial lens, referring to the "mammy syndrome:" White women, in her view, expect Black women "to be understanding and be kind of nurturing because I' $m$ Black and because I understand what it's like to be oppressed."

\section{Conflict between professionals and admins.}

Unlike Asian-Americans, Black women and Latinas reported a lot of conflict between women professionals and administrative support personnel. Said a microbiologist, "I've noticed that administrative staff sometimes they don't respect people. I don't even know if I would use the word 'respect,' but I think they respond differently to when they have a male boss than a female boss. I've seen it with my own eyes and it's unfortunate." She noted this issue can become more complicated for women of color.

A few women also felt that admins expected women professionals to do a specific kind of office housework: emotion work. Said a Black female doctor, "I do think that there's an expectation from female staff that the female supervisors will be more - will be easier, will be more nurturing, will be more understanding, for example, if they have to leave if - because of their families..." She continued: "staff are less tolerant of women who are not like that.... I think that often causes problems between female staff and female supervisors."

She also felt there was a racial dimension that fueled conflict between herself and White administrative support staff. Black women support personnel, she noted, "do not expect me to want to know anything about their personal business. But yet, we are very respectful to each other... I feel that I know these women well and that we're good colleagues and work well together. And if I go and ask them for something, they try their best to help me. And the same with me." But there's "no expectation of knowing people's lives." In contrast, "White women share a lot of personal business, and it's a bonding with them. And I don't think that that expectation occurs among Black women."

\section{Mommy wars.}

Black women also spoke less of mommy wars. An engineer noted that older colleagues sometimes advised younger colleagues "not to take advantage of their rights" to things such as maternity leave and stop-the-clock. Another Black woman discussed her advisor, who said, after she got pregnant, that after the grant finished, she'd have to leave. "So it was very upsetting. So I wrote a letter stating what I had done and how I had kept up even though I had to take some time off. But, essentially, she was saying, 'Having a family is more important for you. You should just stay home and do that. I don't think you can be - have an academic scientific career." She was remarkably understanding, saying "You have to deal with it and try to understand it and 
know that they were doing the best that they knew how.... [You] could see in her face" that the senior woman had had lots of disappointments, "and I think lots of regret." In her view, the senior women "didn't mean any harm. They were I guess trying to protect me from grief."

\section{Latinas}

\section{Tokenism.}

One Latina engineer observed that she has seen women very much taking care of their turf. "It's, 'If I let go of this turf, then who am I? I'm not going to let the younger women in,' even though I'm here telling them that I will let them in. And when you hear the words it's, 'Yes, yes, yes. Let's do this. I'll let you in. I want you to succeed.' But when you start getting close to succeed, the doors just start closing." Another Latina, a doctor, was very selfreflective about how Tugs of War stem from tokenism, specifically from the tendency to compare women with women. "I'm facing a difficult promotion right now," she said, "because I don't have good NIH funding. And one of my female colleagues who's a few years ahead of me, and she's doing really well right now, I'll admit, I'm jealous. And part of it is every success that she achieves makes me look worse...."

\section{Prove-It-Again pass-through.}

A Latina engineer described generational conflict surrounding work-life balance. The older women, she said, "were just very, 'This is what we need to do. This is how we do it now.' They just don't care about anything else. They just want to work, work, work, and prove themselves all the time. I struggled with that a lot because I felt that you should have a little bit more balance."

\section{Tightrope pass-through.}

One Latina reflected on women divided by the masculine-feminine balancing act: "There's so few females that if you are the type to sort of dress up and be very girly you'll be kind of on your own because most of the females that are in the department are not the girly type."

\section{Conflict between professionals and admins.}

Like Black women, Latinas reported a lot of conflict with admins. One scientist was very aware of the racial dynamic involved, saying "conscious or unconscious," there is resistance based on the fact that "there is this Mexican woman telling them what to do." "I have heard administrative assistants say that they would not want to work with a woman boss because they're harder to work with - which I thought was astounding. This was an older White woman who said this, who had been working for a White male for a very long time and we hired a minority woman and she did not 
want to work for her. Her expression of that was, 'I don't want to work for a woman.' I don't know how much of it was truly gender or gender bias and how much of it was ethnic, race related...It was easier to say, 'I don't want to work for a woman,' than, 'I don't want to work for a Latina woman.," Another Latina agreed that a racial dynamic is sometimes involved, saying "most of the times female bosses have a lot more resistance from other females in the group, not from everybody, but it happens especially if there's a difference in race." She described a White woman who had "a lot of resistance from African-American women working under her." Another Latina also felt that "African-American females are much more reluctant to work with a White female. It is a big, big, big issue." The interviewer asked whether they could work with Latinas. "No, no, no. They will work with other African-American women or with males."

Others framed the issue as one of gender. An engineer noted that admins expressed the view that their women bosses were "too demanding. I said, 'Well, but, the boss that you had before was equally demanding. The guy that you were working under was equally demanding.' 'Yeah, but, it's different.' I said, 'What is the difference?' 'Well, that she's a woman. And she should understand that we - sometimes we don't want to do this.' I said, 'Well, no, but the thing is, the work is one, and it has to be done.' In particular, for example, that they will be more lenient if they have to leave or if they don't feel like coming one day or there's a deadline that they have to allow them a little bit, slacking a little bit more the deadline, which they would never do with a male boss." Others felt that age also played a factor. Said one Latina, "I don't know if it was also age.... I was younger than her.... And she felt like, you know, 'How could this young person be my boss and make me wait. You know, I'm working 30 extra minutes here. This is completely unacceptable,' kind of thing."

Several other Latinas reported that support personnel undercut their authority by calling women by their first name but men by their titles. Said one Latina, "sometimes you go and talk to one secretary and there is a group of faculty in the room and she addresses you by your first name but addresses everybody else as doctors. You're like well I'm also a doctor what is the difference here?"

\section{Mommy wars.}

The pass-through was clearest from the comments of a doctor, who said, "People are surprised - they're still, even at this age, that they're surprised that you can have children and still continue to do research and hopefully do good work. If you meet other women that are not in science and having decided to be primary caregivers to their children, those are the ones that precisely tell you, 'Well, I could never do that...." Note how one group of mothers is judging another group as bad mothers. Another mother reflected, 
"If women don't have children, then a scientist - we tend to think, 'Well, of course they can do great work.'... Then sometimes we tend to ascribe their success to the fact that they don't have children... which is probably not fair to them either."

If mothers judge non-mothers, women without children judge right back. Said an engineer, "I think at first I was a little bit shocked and hurt because I had been working with her. It really made me say, 'Hey, I'm not just - I believe in family, and I believe in becoming a mom. I believe in doing that, but I also believe in having a career.' It just made me push harder to get my degree." Said a doctor, "There's that interesting internal gender bias with women who aren't supportive of my decision not to have a family, as if that undermines the whole women's cause [chuckles.]"

\section{Women without children have "no life."}

Latinas without children were far more likely than other women to report assumptions that they should work all the time because they had "no lives" outside of work, which of course fueled resentment by the women without children. One described the White male chair of her department, who would say, "'Oh, since you don't have children, can you please do this evening thing since you don't have a family to go home to?'... And so, one day I said, 'You know what? I have a family. It's composed of a husband, and I want to be home in the evening as well. So you're discriminating against me because I have no children.' And that put a pretty quick stop to that.... And if you are reluctant to get the mothers or the fathers away from their children, then don't have these functions at night."

Latinas reported that pressures on women without children came from men as well as women. Said an engineer, "a lot of my female friends who had children started actually putting a lot on me as in, 'We have kids. Can you do this? Can you stay over this meeting? Can you do this committee for me? Can you do all of these extra things for me because I have kids?"' She continued, "they let me put the extra hours in for them and let me put these extra hours - let me do this extra thing and just one more.... We're actually bringing up that kind of bias and trying to have a very open talk between the women who have children and women who don't." "Where it shows up most," said an engineer, is "when I' $m$ writing proposals with women who do have children, I always get sent the proposal by 5:00 p.m. and be asked to have my revision back by morning because they cannot work at night and I can." "[T] hat happens a lot," she noted. Another Latina mused, "At the moment, I was probably mad at the women that had children, thinking "Why should I, who do not have children, pick up the slack for the women that have children? It's a choice.' And then, of course you think about this for 10 minutes, and you realize it's not the women you need to be pissed off at. It's the men that make the assignments...." Note how, at first, her anger at gender bias was 
directed against other women. Then she made a self-conscious correcting, recognizing that gender bias was also putting other women in a difficult situation.

\section{Women of Color also Experience Bias that Does Not Fit the Four Patterns Template}

Although women of color experience the same bias patterns encountered by White women (often in somewhat different ways), they also experience patterns of bias that do not fit the Four Patterns template.

Most notably, nearly half of Black women (48.0\%) and Latinas (46.9\%) report having been mistaken for administrative or custodial staff, an experience far less common for White (32.4\%) and Asian-American (23.3\%) women scientists. Black women tend to attribute this to their race $(44.12 \%)$ while White women (37.8\%) and Asian-Americans (26.7\%) tend to attribute this to gender, with Latinas about evenly split (29.2\%: gender, $22.9 \%$ : race).

This reflected a general pattern. Black women generally were more likely than other groups to attribute bias to race as opposed to gender. For example, Black women (43.8\%) tended to attribute prove-it-again problems with both their colleagues and students to their race, whereas the other three groups tended to attribute them to gender.

All groups of women tend to attribute tightrope problems to gender. All groups of women tended to attribute pressures to play traditionally feminine roles to gender, although Black women and Latinas were less likely to do so than Whites and Asian Americans. All groups again attribute backlash for assertiveness and self-promotion to gender, although race still is more salient for Black women than for other women. Black women were more likely to attribute pushback for expressions of anger to race, whereas the other three groups of women tend to attribute them to gender.

In addition, each group of women of color reported experiences that differ substantially from those of White women - and each other.

\section{Black Women}

\section{Isolation.}

The interviews with women of color reflected a sense of bleak isolation not evidenced by Williams' interviews of White women (using the same protocol) (Williams \& Dempsey, 2014). A microbiologist reported "feelings of inadequacy" and "some depression," which she attributed to racial bias. "It just takes you longer," she said, "because you really don't have the support that you need." 
This isolation sometimes reflects exclusion. Said a biologist, "So a lot of times, there are things that people exclude me from because they say, 'oh, she would be uncomfortable...' [T] hey think for me... 'Oh, well, she's going to be the only Black person there... just don't invite her, she won't feel comfortable."

Another biologist described "Isolation... you don't know who you can trust.... And alienating - this has been a very lonely life." Another scientist said she did not socialize with her colleagues because, "when you get to know people more socially, that's where the - to me, that lessens your authority." She worried that, as a junior person, if "it's too social, then I think there's a greater risk of you being put in that subservient position, or being looked at that way." She attributed this problem to gender, but it is a problem only Black women mentioned - and they mentioned it often.

"Do I socialize with any of my colleagues?," said a doctor. "Not really." Official office parties she attended but just, “'Oh, it's after work. Let's go get a drink and hang out.' I don't really do that and I guess part of that, particularly with the men in the division, I don't want to lose that edge, I guess. I don't want it perceived as, 'Well, you know, she comes out drinking with us. She's just one of us so we can treat her however."'

Although Black women (41.7\%) were the most likely to report on the survey that "I feel that socially engaging with my colleagues may negatively affect perceptions of my competence," many Latinas (37.5\%), AsianAmerican women (36.4\%), and White women (31.8\%) reported the same thing - but this pattern showed up only in interviews with Black women. "I do not discuss personal things with people," said a microbiologist. "Judge me for me, not my personal life." She said she kept her personal life separate because "I don't want anything in my family life to be used against me."

\section{Racial stereotypes.}

Black women also reported being openly confronted by negative racial stereotypes. The post-doctoral advisor of a biologist "turns to me and says, hey, do you have any family on drugs or in jail..." Another recalled when a professor made a comment about how she would understand about rats because she came from an urban area "and everyone laughed. I didn't think it was funny. And that no one - and that the other students, specifically my colleagues didn't - my female colleagues didn't understand why I was upset or more so offended. And so, when explaining the situation in class many of the White female students thought that they were being overly sensitive and that they just needed to get over it." Another biologist recalled starting a new job where she was the only Black person and a lot of people came in and started telling her negative stories about people of color. "I didn't think much about it," she said. "But I just thought it was strange that she just came out and told me that her parents just didn't like African Americans and that they 
still don't now and that when African Americans moved in their neighborhood during that time period that it was a lot of tension. And I was just like, oh, okay."

\section{Latinas}

\section{Isolation.}

Isolation came up less often among Latinas. However, a Latina geographer had a different take on social isolation, saying that White people are "afraid of people of color in a way, like just worried about like they're going to say the wrong thing or do the wrong thing. So they avoid that entirely."

\section{Disrespect.}

A distinctive flavor springs out from some of the interviews of Latinas in STEM: disrespect. A Latina in chemical and biomedical engineering learned from a student that one of her colleagues had "called me nauseatingly stupid in class to the other students." The comment still haunts her, she said. Every time she doesn't get a grant, "the first thing that comes to my mind is, 'Well, he did indeed tell me that I was nauseatingly stupid, and that's probably why I'm not getting this grant,' even though I have grants.... [T] here's a lot of that internalizing. And after talking to a lot of women who are minorities, there's a lot of that."

\section{Racial stereotypes.}

More commonly, Latinas encountered racial stereotypes. "Just comments here and there, assumptions people made, 'Oh, you're Hispanic so you love tacos and you love spicy foods.' That's not true. Just, 'Oh, you're very into drinking and music,' and just stereotyping, a lot of stereotyping," said a bio-engineer. A neuroscientist recalled a "joke": "Oh, be careful. She's Puerto Rican and she may be carrying a knife in her purse."

A woman of Mexican heritage commented, "There seems to be a stereotype that, if you are from Mexico, you are lazy, and you only like to either sleep by a cactus or party. And I've really battled extremely hard all of these stereotypes. I work really hard at it." Note how she attributed her Prove-ItAgain problems to race rather than gender, and felt the brunt of negative competence assumptions based on race. "I have actually heard people discuss Hispanic people as being lazy," said a Latina in anatomy. "I immediately tell them that my mother is Mexican-American, and that usually makes them very uncomfortable. At which point I've even had people say, 'Oh but you're just half." Another Latina noted that pervasive image "of the friendly Mexican or the passive Mexican or the disorganized Mexican, you know, I am much more organized than the average faculty member in my department. And the ethnic stereotype wouldn't tell you that. People would think that, you know, 
we Mexicans are always late, and we're disorganized." A woman originally from Brazil also encountered stereotypes, saying that Whites "tend to think Brazilians are very friendly and approachable. Even I don't know party animals maybe.... Because the only image that they show about Brazil most of the time on TV internationally is Carnival, right, Mardi Gras. It is soccer time and World Cup time when everybody's on the street jumping around and laughing and having fun."

\section{Assumed to be janitors.}

Latinas encountered persistent assumptions that they were janitorial staff, even if they had on white lab coats. A statistician said that she accepted that perhaps she is around the lab when other professors aren't "but they assume that I am the janitor, okay?...I always amuse my friends with my janitor stories, but it has happened, not only at weird hours." She calmly informed someone that she only had the key to the office, not the janitor's closet.

\section{Assumed to be admins.}

Latinas also are assumed to be administrative support staff. "First thing, for a woman, they always assume I am the secretary of the faculty around, so if they see my door open, they come and ask me if doctor so and so, somebody that doesn't have a doctoral degree, but they assume, because he's a man, that it's a doctor. They come and they ask me if doctor so and so is going to come. I said, 'I don't know. You'll have to ask him.' First, they assume I am the secretary for all the faculty around, and second, sometimes they assume I am the janitor, even during office hours."

\section{Accent discrimination.}

One Latina also encountered accent discrimination, noting that a colleague is "very open with me, and he says, 'Yeah, in the moment you open your mouth and you have an accent, people dismiss what you are saying,' so my greatest barrier is that people listen to what I say and not how I talk." She commented, "You develop a thick skin."

\section{Asian-American Women}

\section{Racial stereotypes.}

Asian-American women also reported stereotypes, notably the "forever foreign" assumption that they were foreigners. Said a physicist, "I've had a number of conversations where people ask me where am I from. And the answer I'm from Pittsburgh is really not what they want, right? And the fact of the matter is that I grew up in Pittsburgh, Pennsylvania, and I went to an expensive private school and then I went to Princeton and Cornell. So, I've had like sort of a really high end Ivy League education, right? And I speak English 'surprisingly well.' I should speak English surprisingly well," she noted dryly. 


\section{Isolation.}

Again, isolation came up less commonly among Asian-American women than among Black women. But for some, it was a factor. Said an astrophysicist, "I don't look like anybody else along any dimension. And that has been very, very isolating. Very, very isolating...."

\section{Demeaning comments.}

A biologist recalled a diagram "to illustrate our department and the expertise and who interacts with who," drawn by the department head "with three circles overlapping. I am in one of those circles way out on the edge and I said, 'You know if I am a little bit more to the right, I would be outside the department." Again, this kind of demeaning comments did not emerge in interviews with White women.

\section{Accent discrimination.}

An immunologist said that her colleagues made fun of her accent when she was a student. One told her, "oh, if you can speak English without accent and then you can come back and discuss with me.... I was very angry. I reported to my mentor" who told her "don't ever write anything down if you cannot say anything nice." So she let it go.

\section{Conclusion}

Of the 60 scientists interviewed for this study, only one was Native American. While she is not necessarily representative, her viewpoint highlights how race can deeply shape the ways women of color experience gender identity, and gender bias. While she said that each of the four patterns of bias sounded familiar, she felt that the challenges she had faced were attributable more to "cultural differences" between herself and members of the "dominant society" than to gender.

She repeatedly raised the difficulty she faces in relating to her colleagues, particularly White men. "I come from a totally different culture." She likened her experiences communicating with members of the dominant culture to "two aliens meet[ing]." "There's no common understanding..." To be a scientist who is also a Native American, "You have to be okay with being totally ostracized in every way.... You have to be willing to continually confront that." Her lack of a support group meant that she had to advocate for herself.

In addition, her experience of the Tightrope was unique. She explained that the gender roles in her culture are the "reverse" of the roles in "dominant society." She described how in her culture, women are considered more confident and dominant and typically play the "provider" role, whereas men are considered "submissive." "In our culture, it's more common for women to do really well in sciences, and engineering, and things like that, than it is 
for men," she noted. "In my society, I'm the man. [Laughter.] I'm not the woman. The men in my society are your society's women," she observed. She believes her strong, dominant manner leads to clashes with male colleagues who expect her to behave in a more subservient way. She recounted that when she has a dispute with a White man, she often seeks advice from White women on how to act. "It's just I can't automatically receive that cultural information that a White woman would [have], but I don't."

In sharp contrast, her concerns raised about the Maternal Wall were similar to those raised by other women. She observed that many women in her field "do not have children and delay childbirth for a very long time to pursue career interests.... I've thought about it myself, and I don't know what the solution is. I personally am planning to have children in my late $30 \mathrm{~s}$ simply because of the career issue. If you would have asked me when I was 22, 'When are you gonna have your first child?' I was happy to think, 'Oh, 27 ... I'll have my career going by then. Things'll be set.' No. Wasn't true. Twenty-seven came and went. Then, when I was 27, I did the readjustment. I was, 'Maybe 31, 32.' Nope. That didn't happen. Now, I'm, 'Maybe 38.' [Laughter.]"

This interview serves to highlight just how little is known about the experience of women of color, how little is known about how the experience of gender and gender bias differs by race, and how little is known about how racial bias is experienced in science. This report cannot fill that void - far from it. But our hope is to help the many well-intentioned people working to retain women in STEM to forge new, more inclusive conversations in which women's varied experiences feel honored, and in which a broad range of women feel included.

\section{Bias Interrupters}

Most of the research on interrupting subtle bias has focused on selfmonitoring (e.g., Rudman, Ashmore, Gary, 2001). Williams has developed a different approach that focuses on redesigning basic business systems to interrupt subtle bias in real time (Williams, 2014), a model of organizational change called "Metrics-Driven Bias Interrupters."

The basic model has four steps:

1) ASSESS. Using interviews or focus groups, investigate whether, and how, subtle bias is playing out in your institution in hiring, Rank and Tenure processes, compensation, and elsewhere. Where bias is suspected, identify an objective metric that will measure whether bias exists.

2) IMPLEMENT A BIAS INTERRUPTER. Put in place a Bias Interrupter.

3) MEASURE. Measure to see if the intervention interrupted the bias effectively enough so that the metric improved. 
4) RATCHET UP IF NECESSARY. If the metric did not show improvement, strengthen or modify the Interrupters until it does.

This report will allow STEM departments to jump over the first step of determining whether subtle bias exists, and move directly to developing objective metrics to assess how the bias is playing out in everyday ways.

\section{Example: Start-up packages}

1) ASSESS. Measure start-up packages of men and women in your department. Is there a patterned difference? While you are at it, compare the start-up packages of different racial groups.

2) IMPLEMENT A BIAS INTERRUPTER. Change procedures to interrupt bias. You might start with a gentle interrupter, say by assigning each professor a mentor as soon as a job offer is made, with a mandate to help the candidate successfully negotiate a fair start-up package.

3) MEASURE. Did the metric improve?

4) RATCHET UP IF NECESSARY. A stronger interrupter would be to have the department chair negotiate all start-up packages, described below.

\section{Example: Office housework}

1) ASSESS. Use interviews or focus groups to identify the kinds of "office housework" that exist in your department. Here are some common types:

- Routine housework: Planning parties, scheduling meetings, ordering supplies, taking notes, doing other administrative tasks or (literal) housework.

- Undervalued work: Mentoring other people's students, serving on lowpower committees, putting on programs for students, etc.

Once you have identified the office housework, develop objective metrics to measure who is doing it, e.g., by analyzing the membership of high-power versus low-power committees over a period of years; or a survey given to both male and female faculty members asking whether they have done various tasks (e.g. planned a party, mentored another professor's students, ordered equipment).

2) IMPLEMENT A BIAS INTERRUPTER. If women are planning the parties, assign an admin to plan the parties. If women are ordering equipment, establish a rule that each professor orders his or her own equipment, or that admins order all equipment. If women are mentoring other people's students, implement a system whereby professors notify the department chair each time they mentor another professor's students.

3) MEASURE. Follow up to see whether the "housework" is more evenly distributed among professors.

4) RATCHET UP IF NECESSARY. For example, if women are still mentoring far more students than men, it may be time to establish clear rules, e.g. that professors all make time to mentor their own students, or that 
professors who spend a lot of time mentoring the students of others are relieved of committee work (on the grounds that their service is mentoring).

\section{Best Practices}

Throughout recruiting, hiring, tenure and promotions processes

1. Send a clear message that stereotypes exist, but that they can be overcome - and that the institution has a commitment to controlling them. An experiment found that merely informing people of the existence of stereotypes risks increasing the penalties incident to stereotyping. This can be controlled by communicating that a "vast majority of people try to overcome their stereotypic preconceptions" - a simple statement that sharply reduced stereotyping, and the penalties to diverse candidates often associated with it. http://psycnet.apa.org/psycinfo/2014-43472-001.

\section{Recruiting and Hiring}

Guide to best practice:

http://sitemaker.umich.edu/advance/files/HandbookforFacultySearchesandHi ring.pdf.

1. Defining the parameters of the search. Defining the parameters of the search in too narrow a way can bleach women out of the application pool in many fields, particularly those with few women. For excellent guidance on how to define a search, see http://advance.cornell.edu/documents/planningthe-search.pdf.

2. Drafting the advertisement. Ads that use masculine-gendered words like "competitive," "assertive," and "ambitious" tend to decrease the number of women applicants (Gaucher, Friesen, \& Kay, 2011). Because women in STEM are far more likely than men to have a professional spouse, it is important to signal openness to dual-career hiring. For a good example of language that signals openness to diversity and dual-career hiring, see http:// advance.cornell.edu/documents/Sample-Lang-for-Ad.pdf.

3. Reviewing resumes. When women musicians began to audition behind a screen, the percentage of women hired by symphony orchestras increased by $46 \%$ (Goldin \& Rouse, 2000). Initial resume screenings should be blinded for race and gender wherever possible. Establish criteria before screening begins to avoid "casuistry:" an experiment found that, when a man had more education, subjects tended to choose the man and cite education as important, whereas when a woman had more education, they tended to hire the man and cite experience as important (Uhlmann \& Cohen, 2005).

4. How to conduct a search process to control for bias. For an excellent, evidence-based protocol for the search process that is designed to control for bias, see http://advance.cornell.edu/documents/Vet-School-Search-Process.pdf. 
5. Require an evidence-based bias training of each search committee. For examples: http://search.committee.module.rutgers.edu/otherAAUs.shtml.

A training available to all will soon be posted on toolsforchangeinstem.org. Best practice: the University of Florida requires that every search committee member participate in an online training module; a refresher course is required every three years.

6. Manage the campus visit to control for bias. For an excellent, evidencebased protocol for how to handle the campus visit to control for bias, see http://advance.cornell.edu/documents/Managing-the-Campus-Visits.pdf.

7. Provide structured way to provide feedback on the candidates. For an excellent form designed to control for bias, see http://advance.cornell.edu/ documents/CandidateEvaluationTool.pdf.

8. Legal and illegal questions. For a good brief guide, see http://www. hr.umich.edu/empserv/department/empsel/legalchart.html. A fast-growing area of employment law involves lawsuits by mothers, and others, for discrimination based on family responsibilities. To avoid problems, see http:// advance.cornell.edu/documents/October2010EmployerAlert.doc.

9. Dual-career hiring and other family friendly policies. Women scientists are far more likely than male scientists to be married to other scientists, so a dual-career hiring program is vital to successful recruitment of women. For a good model universities can use in preparing an FAQ for search committees, see http://www.advance.rackham.umich.edu/FAQDualCareer.pdf. For a good guide for university administrators on how to establish a best-practice program, see http://gender.stanford.edu/sites/default/files/DualCareerFinal_0.pdf.

10. Start-up packages. Women who negotiate hard tend to encounter backlash (Bowles, Babcock \& Lei, 2007). Some department chairs at the University of Michigan negotiate for resources with a list of requested items from potential new hires. http://worklifelaw.org/wp-content/uploads/2013/01/ Effective-Policies-and-Programs-for-Retention-and-Advancement-of-Womenin-Academia.pdf\#cb2.

\section{Committee Assignments \& Other Office Housework}

Divide high-profile glamour work committees from low-profile "office housework" and keep track of how many committees and other service obligations male and female faculty have. If there's a significant imbalance, interrupt the bias by redistributing assignments (or at least limiting the number of low-power committees women serve on).

\section{Promotion and Tenure}

1. Self-promotion. Processes that require people to brag will push women onto the tightrope - disliked but respected if they do, and liked but not 
respected if they don't (Rudman, 1998). Self-promotion should be limited to formal contexts in which both men and women are sent the message that everyone is expected to share his or her accomplishments. Best practice: the department chair asks everyone for their accomplishments periodically and sends around a list. Best practice: establish a norm discouraging selfpromotion in informal contexts.

2. Language in P \& T Letters. Put language in all Rank and Tenure letters to ensure that people are not penalized for stopping-the-clock and/or using parental leave policies, following the example of the University of California, Davis. http://worklifelaw.org/wp-content/uploads/2013/01/ Effective-Policies-and-Programs-for-Retention-and-Advancement-of-Womenin-Academia.pdf\#cb2

3. Bias check. Have someone trained in the Four Patterns of Gender Bias read through all P \& T letters to check for common patterns of gender bias. Provide a feedback loop to faculty colleagues whose letters consistently reflect bias; obviously, this feedback loop has to be designed carefully in order not to trigger backlash. Trainings will soon be available at www.worklifelaw.org.

4. Student evaluations. Evaluations should be presented as distributions rather than averages, in order not to penalize women for polarized evaluations (Fleming, Petty, \& White, 2005; Linville \& Jones, 1980). When evaluations are polarized, analyze whether the dynamic has been affected by race and/or gender. Provide coaching for women and minorities who have polarized evaluations.

\section{Climate}

In addition to the many excellent climate surveys available on-line, two specific issues emerge from the bias literature.

1. "Screamers" and Bullying. A department climate that tolerates bullies and "screamers" will systematically disadvantage women and people of color. This is because prescriptive gender bias means that women often are punished for open displays of anger even in environments where men find that displays of anger actually increase their status (Brescoll \& Uhlmann, 2008). Both Black men and Black women tend to encounter backlash if they are seen as "angry Blacks." In addition, in a social context where Latinos (probably of both sexes) are often written off as overly emotional ("fiery Latins") even if they don't show anger, open displays of anger may well also carry negative consequences for Latinos.

2. Self-promotion. A departmental climate that encourages open selfpromotion also will systematically disadvantage women. This is because prescriptive gender bias means that women who self-promote often trigger dislike and other forms of backlash, even when men are doing precisely the same thing (Rudman, 1998). The Interrupter is to limit self-promotion to 
formal contexts or, if that's impossible, at least to establish formal ways in which women can publicize their accomplishments in a way that seems socially appropriate. Examples are a monthly email from the Chair publicizing publications, conference presentations, grants, prizes and other accomplishments of members of the department or - better yet - a section of departmental meetings that does so. This also will help modest men, who encounter pushback when they don't self-promote (Moss-Racusin, Phelan \& Rudman, 2010), as well as Black men, who often encounter a backlash when they do (Hall \& Livingston, 2012).

\section{Trainings}

An influential study found that trainings did not improve outcomes for women and diverse candidates (Kalev, Kelly, \& Dobbin, 2006). This study did not control for the quality of the training provided. Its findings probably were influenced by the many unscientific, sensitivity-type trainings offered by diversity trainers.

Particularly in science, evidence-based trainings are required. The ideal is where information about subtle biases is built into trainings that also cover other, "hard" topics. An example is a Training for Search Committees that discusses their duties and university procedures, and also discusses how biases can creep into hiring decisions. Bias training should be incorporated into annual workshops for Department Chairs and Search Committees.

For online trainings to address gender bias in STEM, see http://www.tools forchangeinstem.org/workshop-catalog/ and http://www.hunter.cuny.edu/ gendertutorial/tutorial1.html.

For an online training on bias designed for department chairs, see http:// www.toolsforchangeinstem.org/workshop-catalog/ (Building a Department in an Era of Tight Budgets: It's Cheaper to Keep Her).

For an online training that focuses on how to avoid legal liability related to gender bias, see http://www.toolsforchangeinstem.org/workshop-catalog/ (Some Things Are Illegal).

An effective model for delivering bias training is the STRIDE program at the University of Michigan. STRIDE recruits full professors to participate in an ongoing committee that provides advice on how to recruit and retain a diverse faculty. Each STRIDE member attends three half-days of training and reads from a recommended reading list. They receive teaching relief for participating in the program. Colleagues then can request that a STRIDE member lead workshops for department chairs, search committees, and in other venues to educate their peers. 


\section{Parenthood and Family Caregiving}

For trainings for department chairs and others on parenthood and science, see http://www.toolsforchangeinstem.org/workshop-catalog/ (Do Babies Matter?; The Competitive Edge: Best Practices for Family Friendly Policies).

For a comprehensive list of best family friendly practices, see http:// www.worklifelaw.org/pubs/worklife_academia_FINAL.pdf.

\section{Appendix}

Survey respondents were recruited through the Association for Women in Science (AWIS), which sent emails to its membership recruiting participants.

Interviewees also were recruited through AWIS. Interviewees, who are all scientists, were equally divided between Latinas, Asian-Americans, and Black women, with one interview of a Native American.

Breakdown of survey respondents:

\begin{tabular}{|c|c|c|}
\hline Race of Respondent & $\mathbf{N}$ & $\%$ \\
\hline White/Caucasian & 398 & 72.4 \\
\hline Black/African-American & 26 & 4.7 \\
\hline Hispanic/Latino & 32 & 5.8 \\
\hline Asian & 45 & 8.2 \\
\hline Native-American & 2 & .4 \\
\hline Pacific Islander & 0 & 0 \\
\hline Mixed Race & 39 & 7.1 \\
\hline Other & 8 & 1.5 \\
\hline Total & 550 & $100 \%$ \\
\hline
\end{tabular}

\section{NOTE}

This material is based upon work supported by the National Science Foundation under Grant Number (1106411). Any opinions, findings, and conclusions or recommendations expressed in this material are those of the author(s) and do not necessarily reflect the views of the National Science Foundation.

\section{REFERENCES}

Allen, T. D. (2006), "Rewarding Good Citizens: The Relationship between Citizenship Behavior, Gender, and Organizational Rewards," Journal of Applied Psychology 36(1): 120-143.

Almquist, E. M. (1975), "Untangling the Effects of Race and Sex: The Disadvantaged Status of Black Women," Social Science Quarterly 56(1): 129-142.

Baez, B. (2000), "Race-related Service and Faculty of Color: Conceptualizing Critical Agency in Academe," Higher Education 39(3): 363-391.

Bardoel, A., Drago, R., Cooper, B., \& Colbeck, C. (2011), "Bias Avoidance: Crosscultural Differences in the US and Australian Academies," Gender, Work \& Organization 18: e157-e179. 
Bavishi, A., Madera, J., \& Hebl, M. (2010), "The Effect of Professor Ethnicity and Gender on Student Evaluations: Judged before Met," Journal of Diversity in Higher Education 3(4): 245-256.

Benard, S., Paik, I., \& Correll, S. (2008), "Cognitive Bias and the Motherhood Penalty," Hastings Law Journal 59(6): 1359-1387.

Benard, S., \& Correll, S. (2010), "Normative Discrimination and the Motherhood Penalty," Gender and Society 24(5): 616-646.

Berdahl, J., \& Moon, S. (2013), "Workplace Mistreatment of Middle Class Workers Based on Sex, Parenthood, and Caregiving," Journal of Social Issues 69(2): 341-366.

Blackwell, L. V., Snyder, L. A., \& Mavriplis, C. (2009), "Diverse Faculty in STEM Fields: Attitudes, Performance, and Fair Treatment," Journal of Diversity in Higher Education 2(4): 195-205. http://doi.org/http://dx.doi.org/10.1037/a0016974

Bonilla, J. (2006), "Are You Here to Move the Piano?" A Latino Reflects on Twenty Years in the Academy," in Stanley, C. (ed.), Faculty of Color: Teaching in Predominantly White Colleges and Universities. New York: Anker, 68-79.

Bowles, H. R., Babcock, L., \& Lei, L. (2007), "Social Incentives for Gender Differences in the Propensity to Initiate Negotiations: Sometimes It Does Hurt to Ask," Organizational Behavior and Human Decision Processes 103(1): 84-103.

Brescoll, V. L., \& Uhlmann, E. L. (2008), "Can Angry Women Get Ahead? Gender, Status Conferral, and Workplace Emotion Expression," Psychological Science 19(3): 268-275.

Brewer, M. (1996), "In-Group Favoritism: The Subtle Side of Intergroup Discrimination," in Messick, D. M. \& Tenbrunsel, A. E. (eds.), Codes of Conduct Behavioral Research into Business Ethics. New York: Russell Sage Foundation, 160-170.

Buchanan, T. (2005), "The Paradox of the Contented Female Worker in a Traditionally Female Industry," Sociological Spectrum 25: 677-713.

Castilla, E., \& Bernard, S. (2010), "The Paradox of Meritocracy in Organizations," Administrative Science Quarterly 55(4): 543-676.

Ceci, S., Williams, W. M., \& Barnett, S. M. (2009), "Women's Underrepresentation in Science: Sociocultural and Biological Considerations," Psychological Bulletin 135(2): 218-261.

Ceci, S. J., et al. (2011), "Do Subtle Cues about Belongingness Constrain Women's Career Choices?," Psychological Inquiry 22(4): 255-258.

Charleston, L. J., George, P. L., Jackson, J. F. L., Berhanu, J., \& Amechi, M. H. (2014), "Navigating Underrepresented STEM Spaces: Experiences of Black Women in U.S. Computing Science Higher Education Programs Who Actualize Success," Journal of Diversity in Higher Education 7(3): 166-176. http://doi. org/10.1037/a0036632

Cornell University (2012, February 14), "Motherhood 'Detrimental' to Women's Scientific Careers, Study Concludes," ScienceDaily. Retrieved September 24, 2015 from www.sciencedaily.com/releases/2012/02/120214134620.htm.

Correll, S. J., Benard, S., \& Paik, I. (2007), "Getting a Job: Is There a Motherhood Penalty?," American Journal of Sociology 112(5): 1297-1339.

Crenshaw, K. W. (1989), "Demarginalizing the Intersection of Race and Sex: A Black Feminist Critique of Antidiscrimination Doctrine, Feminist Theory and Antiracist Politics," University of Chicago Legal Forum, 139-143. 
Cuddy, A. J., Fiske, S. T., \& Glick, P. (2004), "When Professionals Become Mothers, Warmth Doesn't Cut the Ice," Journal of Social Issues 60(4): 701-718.

Cuddy, A. J. C., \& Wolf, E. B. (2013), "Prescriptions and Punishments for Working Moms: How Race and Work Status Affect Judgments of Mothers," in Robin J. Ely and Amy J. C. Cuddy (eds.), Gender and Work: Challenging Conventional Wisdom. Cambridge, MA: Harvard Business School Publishing, 36-43.

DePaulo, B. M., \& Morris, W. L. (2006), "The Unrecognized Stereotyping and Discrimination against People Who Are Single," Current Directions in Psychological Science 15(5): 251-254.

Derks, B., Ellemers, N., Van Laar, C., \& de Groot, K. (2011), "Do Sexist Organizational Cultures Create the Queen Bee?," British Journal of Social Psychology 50(3): 519-535.

Derks, B., Van Laar, C., Ellemers, N., \& De Groot, K. (2011), "Genders Bias Primes Elicit Queen Bee Responses among Senior Police Women," Psychological Science 22(10): 1243-1249.

Dobson, R., \& Iredale, W. (December 31, 2006), "Office Queen Bee's Hold Back Women's Careers," Sunday Times, available at http://www.thesundaytimes.co.uk/ sto/news/uk_news/article56777.ece.

Duguid, M., \& Thomas-Hunt, M. (2015), "Condoning Stereotyping? How Awareness of Stereotyping Prevalence Impacts Expression of Stereotypes," Journal of Applied Psychology 100(2): 343-359.

Eagly, A., \& Mladinic, A. (1994), "Are People Prejudiced against Women? Some Answers from Research on Attitudes, Gender Stereotypes, and Judgments of Competence," European Review of Social Psychology 5(1): 1-35.

Epstein, S. (1973), "The Self-concept Revisited: Or a Theory of a Theory," American Psychologist 28(5): 404-416.

Espinosa, L. (2011), "Pipelines and Pathways: Women of Color in Undergraduate STEM Majors and the College Experiences that Contribute to Persistence," Harvard Educational Review 81(2): 209-241.

Family and Medical Leave Act of 1993, 29 U.S.C. $\$ \S 2601-2654$ (2006).

Fiske, S. T. (2010), "Interpersonal Stratification: Status, Power, and Subordination," in Fiske, S. T., Gilbert, D. T., \& Lindzey, G. (eds.), Handbook of Social Psychology. 5th edn. New York: Wiley, 941-982.

Fiske, S. T., Cuddy, A. J., Glick, P., \& Xu, J. (2002), “A Model of (Often Mixed) Stereotype Content: Competence and Warmth Respectively Follow from Perceived Status and Competition," Journal of Personality and Social Psychology 82(6): 878-902.

Fiske, S. T., Cuddy, A. J., \& Xu, J. (1999), “(Dis)respecting versus (Dis)liking: Status and Interdependence Predict Ambivalent Stereotypes of Competence and Warmth," Journal of Social Issues 55(3): 473-489.

Fleming, M. A., Petty, R. E., \& White, P. H. (2005), "Stigmatized Targets and Evaluation: Prejudice as a Determinant of Attribute Scrutiny and Polarization," Personality and Social Psychology Bulletin 31(4): 496-507.

Foschi, M. (1996), "Double Standards in the Evaluation of Men and Women," Social Psychology Quarterly 59(3): 237-254. 
Gaucher, D., Friesen, J., \& Kay, A. (2011), "Evidence that Gendered Wording in Job Advertisements Exists and Sustains Gender Inequality," Joumal of Personality and Social Psychology 101(1): 109-128.

Goff, P. A., Thomas, M. A., \& Jackson, M. C. (2008), “Ain't I a Woman?:' Towards an Intersectional Approach to Person Perception and Group-based Harms," Sex Roles 59: 392-400.

Goldin, C., \& Rouse, C. (2000), "Orchestrating Impartiality: The Impact of 'Blind' Auditions on Female Musicians," American Economic Review 90(4): 715-741.

Gruenfeld, D. [Stanford Graduate School of Business] (2013, March 13), "Deborah Gruenfeld: Power \& Influence" [http://youtu.be/KdQHAeAnHmw]. Retrieved from: https://www.youtube.com/watch?v=KdQHAeAnHmw

Foschi, M. (2000), "Double Standards for Competence: Theory and Research," Annual Review of Sociology 26: 21-28.

Frehill, L. M., \& Ivie, R. (2013), "Increasing the Visibility of Women of Color in Academic Science and Engineering: Professional Society Data," New Directions for Higher Education 163: 7-21. http://doi.org/10.1002/he.20061.

Galinsky, A. D., Hall, E. V., \& Cuddy, A. J. (2013), "Gendered Races: Implications for Interracial Marriage, Leadership Selection, and Athletic Participation," Psychological Science 24(4): 498-506. DOI:0956797612457783.

Gutiérrez y Muhs, G., Flores Neimann, Y., González, C. G., \& Harris, A. P. (2012), Presumed Incompetent: The Intersections of Race and Class for Women in Academia. Boulder, CO: Utah State University Press.

Heilman, M. (2001), "Description and Prevention: How Gender Stereotypes Prevent Women's Ascent Up the Organizational Ladder," Journal of Social Issues 57(4): 657-674.

Heilman, M. (1995), "Sex Stereotypes and Their Effects in the Workplace: What We Know and What We Don't Know," Journal of Social Behavior and Personality 10(6): 3-26.

Heilman, M. (1983), "Sex Bias in Work Settings: The Lack of Fit Model," Research in Organizational Behavior 5: 270-298.

Hess, C., Gault, B., \& Yi, Y. (2013), "Accelerating Change for Women Faculty of Color in STEM: Policy, Action, and Collaboration," Women's Policy Research. http:/www.iwpr.org/publications/pubs/accelerating-change-for-women-facultyof-color-in-stem-policy-action-and-collaboration.

Hewlin, P. F. (2003), "And the Award for Best Actor Goes to...: Facades of Conformity in Organizational Settings," Academy of Management Review 28(4): 633-642.

Hewlin, P. F., Dumas, T. L., \& Burnett, M. F. (2014), "Is It Safe To Be Me?: The Effects of Psychological Safety, Race and Leadership on Creating Facades," Academy of Management Proceedings, 14515.

Hollenshead, C., \& Thomas, G. (2001), "Resisting from the Margins: The Coping Strategies of Black Women and Other Women of Color Faculty Members at a Research University," Journal of Negro Education 70(3): 166-175.

Hurtado, S, Eagan, K., Pryor, J., Whang, H., \& Tran, S. (2012), Undergraduate Teaching Faculty: The 2010-2011 HERI Faculty Survey. Los Angeles, CA: Higher Education Research Institute.

Johnson, D. (2011), "Women of Color in Science, Technology, Engineering, and Mathematics (STEM)," in J. G. Gayles (ed.), New Directions for Institutional 
Research. No. 152. Attracting and Retaining Women in STEM. San Francisco, CA: Jossey-Bass, 75-85. http://doi.org/10.1002/ir.410.

Johnson, K. L., Freeman, J. B., \& Paulker, K. (2012), "Race is Gendered: How Covarying Phenotypes and Stereotypes Bias Sex Categorization," Journal of Personality and Social Psychology 102(1): 116-131.

Jones, C., \& Shorter-Gooden, K. (2003), Shifting: The Double Lives of Black Women in America. New York: HarperCollins.

Kachchaf, R., Ko, L., Hodari, A., \& Ong, M. (2015), "Career-life Balance for Women of Color: Experiences in Science and Engineering Academia," Journal of Diversity in Higher Education 8(3): 175-191.

Kalev, A., Dobbin, F., \& Kelly, E. (2006), "Best Practices or Best Guesses? Assessing the Efficacy of Corporate Affirmative Action and Diversity Policies," American Sociological Review 71(4): 589-617.

Kanter, R. M. (1977a), "Some Effects of Proportions on Group Life: Skewed Sex Ratios and Responses to Token Women," American Journal of Sociology 85(5): 965-990.

Kanter, R. M. (1977b), Men and Women of the Corporation. New York: Basic Books.

Ko, L. T., Kachchaf, R. R., Ong, M., \& Hodari, A. K. (2013), "Narratives of the Double Bind: Intersectionality in Life Stories of Women of Color in Physics, Astrophysics and Astronomy," AIP Conference Proceedings 1513(1): 222-225. http://doi.org/10.1063/1.4789692.

Linville, P. W., \& Jones, E. E. (1980), "Polarized Appraisals of Out-group Members," Journal of Personality and Social Psychology 38(5): 689-695.

Livingston, R. W., Rosette, A. S., \& Washington, E. F. (2012), "Can an Agentic Black Woman Get Ahead? The Impact of Race and Interpersonal Dominance on Perceptions of Female Leaders," Psychological Science 23(4): 354-358.

Livingston, P. W., \& Rossette, A. S. (2012), "Failure Is Not an Option for Black Women: Effects of Organizational Performance on Leaders with Single versus Dual-subordinate Identities," Journal of Experimental Social Psychology 48(5): 1162-1167.

Malcom, S. M., Hall, P. Q., \& Brown, J. W. (1976), The Double Bind: The Price of Being a Minority Woman in Science. Washington, DC: American Association for the Advancement of Science.

Mason, M. A, Goulden, M., \& Frasch, K. (2010), "Keeping Women in the Science Pipeline," paper presented at Workplace Flexibility, Georgetown Law School, November 29-30, Washington, DC.

Mitchell, G., \& Tetlock, P. E. (2006), "Antidiscrimination Law and the Perils of Mindreading," Ohio State Law Journal 67(5): 1023-1024.

Moss-Racusin, C. A., Dovidio, J. F., Brescoll, V.L., Graham, M. J., \& Handelsman, J. (2012), "Science Faculty's Subtle Gender Biases Favor Male Students," Proceedings of the National Academy of Sciences 109(41): 16474-16479.

Moss-Racusin, C. A., Phelan, J. E., \& Rudman, L. A. (2010), "When Men Break the Gender Rules: Status Incongruity and Backlash toward Modest Men," Psychology of Men and Masculinity 11(2): 140-151.

Nosek, B. A., Banaji, M. R., \& Greenwald, A. G. (2002), "Math = Male, Me = Female, therefore Math $\neq$ Me," Journal of Personality and Social Psychology 83(1): 44-59. 
O’Neill, O. A., \& O'Reilly, C. A. (2011), "Reducing the Backlash Effect: Selfmonitoring and Women's Promotions," Journal of Occupational and Organizational Psychology 84(4): 825-832.

Ong, M. (2005), "Body Projects of Young Women of Color in Physics: Intersections of Gender, Race, and Science," Social Problems 52(4): 593-617.

Ong, M., Wright, C., Espinosa, L., \& Orfield, G. (2010), "Inside the Double Bind: A Synthesis of Empirical Research on Women of Color in Science, Technology, Engineering, and Mathematics," White paper presented to the National Science Foundation, Washington, DC (NSF/REESE Project DRL-0635577).

Ong, M., Wright, C., Espinosa, L. L., \& Orfield, G. (2011), "Inside the Double Bind: A Synthesis of Empirical Research on Undergraduate and Graduate Women of Color in Science, Technology, Engineering, and Mathematics," Harvard Educational Review 81(2): 173-209.

Prentice, D. A., \& Carranza, E. (2002), "What Women and Men Should Be, Shouldn't Be, Are Allowed to Be, and Don't Have to Be: The Contents of Prescriptive Gender Stereotypes," Psychology of Women Quarterly 26(4): 269-281.

President's Council of Advisors on Science and Technology (2012), "Engage to Excel: Producing One Million Additional College Graduates with Degrees in Science, Technology, Engineering, and Mathematics." Available at http://www. whitehouse.gov/sites/default/files/microsites/ostp/pcast-engage-to-excelfinal_ feb.pdf. (Accessed February 13, 2012)

Reuben, E., Sapienza, P., \& Zingales, L. (2014), "How Stereotypes Impair Women's Careers in Science," Proceedings of the National Academy of Sciences of the United States 111(12): 4403-4408.

Reyes, M. (2011), "Unique Challenges for Women of Color in STEM Transferring from Community Colleges to Universities," Harvard Educational Review 81(2): 241-262.

Richardson, E. V., Phillips, K. W., Rudman, L. A., \& Glick, P. (2011), “Double Jeopardy or Greater Latitude: Do Black Women Escape Backlash for Dominance Displays?," Working paper, Northwestern University.

Ridgeway, C. L., \& Kricheli-Katz, T. (2013), "Intersecting Cultural Beliefs in Social Relations: Gender, Race, and Class Binds and Freedoms," Gender and Society 27(3): 294-318.

Roberts, L. M., \& Dutton, J. E. (2009), Exploring Positive Identities and Organizations: Building a Theoretical and Research Foundation. New York: Routledge.

Rosenwald, A. G. (2011), "Women on the Verge of a Glass-ceiling Breakdown," BioScience 61(10): 823-825.

Rosette, A. S., \& Livingston, R. (2012), "Failure Is Not an Option for Black Eomen: Effects of Organizational Performance on Leaders with Single versus Dual Subordinate Identities," Journal of Experimental Social Psychology 48(5): 1162-1167.

Rudman, L. A., Ashmore, R. D., \& Gary, M. L. (2001), "Unlearning' Automatic Biases: The Malleability of Implicit Prejudice and Stereotypes," Journal of Personality and Social Psychology 81(5): 856-868.

Rudman, L. A. (1998), "Self-promotion as a Risk Factor for Women: The Costs and Benefits of Counterstereotypical Impression Management," Journal of Personality and Social Psychology 74(3), 629-645. 
Settles, I., Cortina, L., Malley, J., \& Stewart, A. (2006), "The Climate for Women in Academic Science: The Good, the Bad, and the Changeable," Psychology of Women Quarterly 30: 47-58.

Sheltzer, J., \& Smith, J.C. (2014), "Elite Male Faculty in the Life Sciences Employ Fewer Women," Proceedings of the National Academy of Sciences of the United States 111(28): 10107-10112.

Stanley, C. (2006), Faculty of Color: Teaching in Predominantly White Colleges and Universities. New York: Anker Publishing Company.

Steele, C. M., \& Aronson, J. (1995), "Stereotype Threat and the Intellectual Test Performance of African Americans," Journal of Personality and Social Psychology 69(5): 797-811.

Sue, D. W., Capodilupo, C. M., Torino, G. C., Bucceri, J. M., Holder, A., Nadal, K. L., \& Esquilin, M. (2007), "Racial Microaggressions in Everyday Life: Implications for Clinical Practice," American Psychologist 62(4): 271-286.

Swim, J. K., \& Sanna, L. J. (1996), "He's Skilled, She's Lucky: A Meta-analysis of Observer's Attributions for Women's and Men's Successes and Failures," Personality and Social Psychological Bulletin 22(5): 507-508.

Trades Union Congress (2008), "Single Women in Their Thirties Do More Unpaid Overtime than Anyone Else," Press release. Retrieved from: http://www.tuc.org. uk/equality-issues/childcare/equal-pay/single-women-their-30s-do-more-unpaidovertime-anyone-else.

Torres, L. E. (2012), "Lost in the Numbers: Gender Equity Discourse and Women of Color in Science, Technology, Engineering and Mathematics (STEM)," International Joumal of Science in Society 3(4): 33-45.

Turner, C. S. V., Gonzáles, J. C., \& Wong, K. (2011), "Faculty Women of Color: The Critical Nexus of Race and Gender," Journal of Diversity in Higher Education 4(4): 199-211.

Uhlmann, E. L., \& Cohen, G. L. (2005), "Constructed Criteria: Redefining Merit to Justify Discrimination," American Psychological Society 16(6): 474-480.

University of Cincinnati (2014, August 11), "Challenges, Strategies for Women Pursuing STEM Careers," ScienceDaily. Retrieved November 10, 2014 from www.sciencedaily.com/releases/2014/08/140811124956.htm.

Williams, J. C., \& Dempsey, R. (2014), What Works for Women at Work: Four Pattems Working Women Need to Know. New York. New York University Press.

Williams, J. C. (2014), "Hacking Tech's Diversity Problem," Harvard Business Review 92(10): 94-100.

Williams, J. C. (2014, January 24), "Women, Work and the Art of Gender Judo," The Washington Post. Retrieved from: https://www.washingtonpost.com/ opinions/women-work-and-the-art-of-gender-judo/2014/01/24/29e209b2-82b211e3-8099-9181471f7aaf_story.html.

Williams, J. C., Blair-Loy, M., \& Berdahl, J. L. (2013), "Cultural Schemas, Social Class, and the Flexibility Schema," Journal of Social Issues 69(2): 209-234.

$\mathrm{Xu}$, Yonghong (2015), "Focusing on Women in STEM: A Longitudinal Examination of Gender-Based Earning Gap of College Graduates," Journal of Higher Education 86(4): 489-523. 